\title{
Cotton textiles from the Byzantine period to the Medieval period in ancient Palestine
}

Textiles de coton en ancienne Palestine, de l'époque byzantine à l'époque médiévale

\section{Orit Shamir}

\section{(2) OpenEdition}

\section{Journals}

Electronic version

URL: http://journals.openedition.org/ethnoecologie/4176

DOI: 10.4000/ethnoecologie.4176

ISSN: 2267-2419

\section{Publisher}

Laboratoire Eco-anthropologie et Ethnobiologie

\section{Electronic reference}

Orit Shamir, "Cotton textiles from the Byzantine period to the Medieval period in ancient Palestine », Revue d'ethnoécologie [Online], 15 | 2019, Online since 30 June 2019, connection on 31 October 2019 URL : http://journals.openedition.org/ethnoecologie/4176; DOI : 10.4000/ethnoecologie.4176

This text was automatically generated on 31 October 2019 .

\section{(c) ()}

Revue d'ethnoécologie est mis à disposition selon les termes de la licence Creative Commons Attribution - Pas d'Utilisation Commerciale - Pas de Modification 4.0 International. 


\section{Cotton textiles from the Byzantine period to the Medieval period in ancient Palestine}

Textiles de coton en ancienne Palestine, de l'époque byzantine à l'époque

médiévale

Orit Shamir

\section{Introduction}

1 Thousands of textiles from the Pre-Pottery Neolithic period onward have been discovered up to now in the Judean Desert and in the Negev and Arava regions (Figure 1) (Schick 1988, Shamir 2016c). The arid climate of the southern Levant helped the preservation of these textiles, offering us a rich picture of textile production and use in ancient Palestine. 


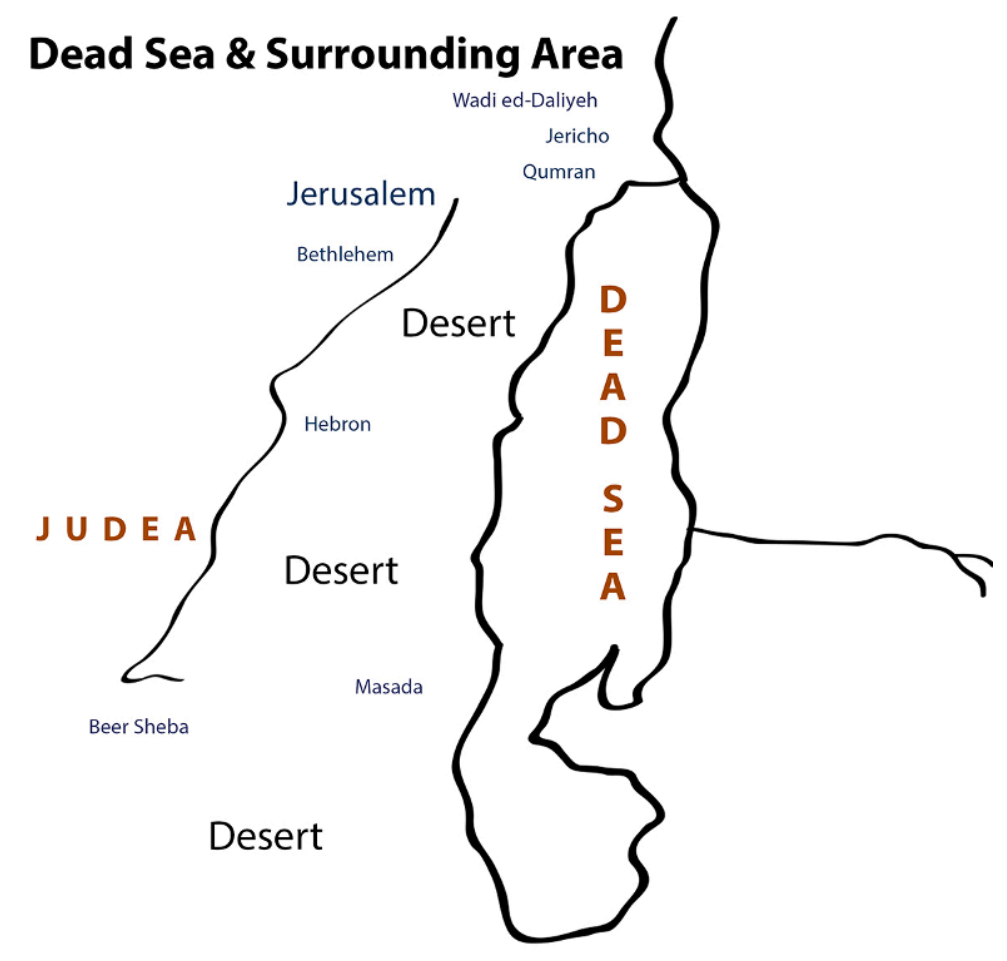

Map Shamir S.

2 This article will discuss the findspots of cotton textiles and the location of their manufacture, questioning the origin of these different cotton fabrics, their provenance, and the route they took to their new owners. Unlike pottery production centres, such as Ramla (Korenfeld 2015), textile production centres almost never leave diagnostic debris such as wooden looms in the archaeological record. Thus, how can we determine where textiles were actually made? Traditionally, textile scholars use the following sources and indicators to answer this question (Shamir 2016c: 231):

1. Places with a concentration of textile finds give indications concerning the dominant material, spin direction, weaving techniques, etc.

2. The location of the earliest known examples of a certain kind of technique.

3. Historical sources.

4. Other archaeological finds such as textile tools (e.g. spindle whorls).

3 New advances in natural sciences, such as Strontium Isotope tracing, opens exciting avenues for the analysis of the textiles' provenance. Yet, the method has only been fully explored in specific regions, notably on Bronze and Iron Age woolen textiles from Scandinavia (Frei 2015, Frei et al. 2009).

In this article I will compare the technical features of cotton textiles, including their spin direction, weaving techniques, dyes, and garments' tailoring, to the available historical sources in order to offer hypotheses as to the origin of these textiles.

5 Spin direction is a very important factor in the textiles' presentation. Spun fibers are described as being S-spun (anti-clockwise) or Z-spun (clockwise). S-spun was typical and predominant in Palestine, from the Neolithic until the medieval period. The Roman 
period notably yielded thousands of S-spun textiles, while only a few Z-spun examples in twill weave were usually interpreted as imports.

Cotton was common in ancient Nubia (Yvanez 2016a et 2016b) but an Indian or Yemeni origin has also been detected in several cases (Golombeck \& Gervers 1977: 83 ; Mackie 1989: 88). In general, scholars view S- spun cotton threads as typical to Nubia, while Zspun cotton characterizes textiles from India and Yemen. But spin direction isn't the sole key to provenance (Wild 1997: 291) and recent research and textile analyses are now questioning this method (Wild this volume).

A detailed technical analysis can also bring a wealth of information, which can then be compared with known weaving traditions from other regions. India for example had developed a highly sophisticated industry producing a variety of cotton products. It excelled in spinning and weaving, but also in the dyeing and decoration of the cloth. The decoration of a cotton cloth in India is characterised by specific designs created through dyeing, printing and painting, a process that entailed a different set of skills based on knowledge of dyes, mordants, process of waxing the cloth, bleaching it, and carving of the wooden blocks (Riello 2014: 98, 102). Such unique production can easily be identified through textile analysis, and a few of these remarkable cotton fabrics have indeed been recognised in the Southern Levant, attesting a lively textile trade between the two regions from the $7^{\text {th }}$ century CE onwards.

\section{Historical Sources}

8 The word cotton (kutna in Hebrew) is not mentioned in the Bible but is mentioned a number of times in rabbinic literature. The rabbinic literature of the Mishnaic and Talmudic periods is a summary of the discussions that were held in the different Judaic schools (batei midrash), particularly in the period between the $1^{\text {st }}$ and the $5^{\text {th }} \mathrm{C}$. CE. The Mishnah served as a guide in the schools of the Talmudic period, and it played a central role in the determination of laws established for subsequent generations. The authors of the Jerusalem Talmud ( $3^{\text {rd }}-4^{\text {th }} \mathrm{C}$. CE) considered the Mishna to be a textbook as well as a book of rules. It is not fully edited and is difficult to comprehend. The Babylonian Talmud ( $5^{\text {th }}$ century CE) is similar to the Jerusalem Talmud in character, but was written in Babylonia (Safrai 1994: 459-462).

9 Judging by the minimal number of references to cotton, it would appear that it was not widely cultivated and was of little importance. In the Mishnah, cotton is referred to as "wool vine" because the leaves of the cotton plant resemble the leaves of the vine, in Hebrew tsemer (fabric) gefen and not tsemen cutnah (Mishnah Kilayim 7:2). According to most commentators, the reference in the Mishnah is indeed to cotton (Herschberg 1924: 92-95; Safrai 1994: 162). In the late $6^{\text {th }}$ century CE, Gregory of Tours, in his book Glory of the Martyrs (Gregory of Tours Glor. mart. 17) writes with convincing details that cotton was growing in the oasis at Jericho (Safrai 1994: 163, Wild 1997: 291, Wild \& Wild 2014a: 212). Therefore, despite the scarcity of contemporary accounts, it seems that the local populations had a sound knowledge of cotton cultivation, if only in selected areas.

By the $10^{\text {th }}$ century $\mathrm{CE}$, cotton was an important agro-industrial product in the economies of both Palestine and Syria, with parts of its output diverted to export. A contemporary source characterized the Hula Lake region as "the source of cotton". It was exported "from Jerusalem and Aleppo" (al-Muqadassî 1960: 160, 180), and a description of its cultivation stresses the importance of cotton in the economy of Syria 
(Millàs Vallicrosa \& Aziman 1955: 115-116, Ducène this volume). In a group of letters dated to the $11^{\text {th }}$ century CE and assembled as the "Geniza documents", Egyptian merchants highly praise the cotton from Eretz-Israel, specifically referring to the coastal town of Ashqelon (Amar 1998: 115). Cultivation of cotton in this region continued during the Crusader-Ayyubid periods. The Crusader conquest brought new momentum to the cotton trade between Palestine, Syria, and Europe, a process which intensified in the Mamluk period ('Amar 1998: 115, Shamir 2015).

11 Many cotton textiles have been found in archaeological sites across modern Israel, now providing fascinating material counterpoints to these historical texts.

\section{Textiles finds from archaeological excavations in Palestine}

\section{Roman period cotton textiles}

12 In Palestine, wool was the most common textile raw material during the Roman Period (900 occurrences out of 1635 textile finds recorded). Linen was also very popular (662 out of 1635 specimens). Goat hair was used, but in much less quantities (58 out of 1635 textiles). A very small number of camel hair textiles was also noted.

In fact, when we look at the archaeological finds, cotton textiles have not been found in significant numbers in Palestine before the Byzantine period $\left(4^{\text {th }}-7^{\text {th }} \mathrm{C}\right.$. CE). The only earlier occurrence is a cotton net dated to the $3^{\text {rd }}$ century CE (F igure 2), found in Jerusalem, in the Jewish burial known as "Jason's tomb" (Rahmani 1967: 93-94). The net has been dated to $210 \pm 20 \mathrm{CE}$ by radiocarbon determination ${ }^{1}$. We need to turn to neighboring Jordan to find other occurrences. One Roman cotton textile as well as cotton sewing threads in a linen tunic were found at Khirbet Qazone - a cemetery of 3500 graves, most of them ransacked (Granger-Taylor 2000, Politis 1998 et 1999, Shanks 1999). The site is close to the highway linking the towns of al-Mazra'a and Safi, just southwest of Bāb adh-Dhrā'. Originally on the eastern shore of the Dead Sea, it is now separated by kilometers of salty land from the water, as a result of centuries-long evaporation. The site is dated to the $1^{\text {st }}$ and $2^{\text {nd }} \mathrm{C}$. CE, while some of the textiles have features that point to the $3^{\text {rd }}$ century CE. 
Figure 2: Cotton net, Jason tomb, Jerusalem, Roman period, IAA no. 56-1421

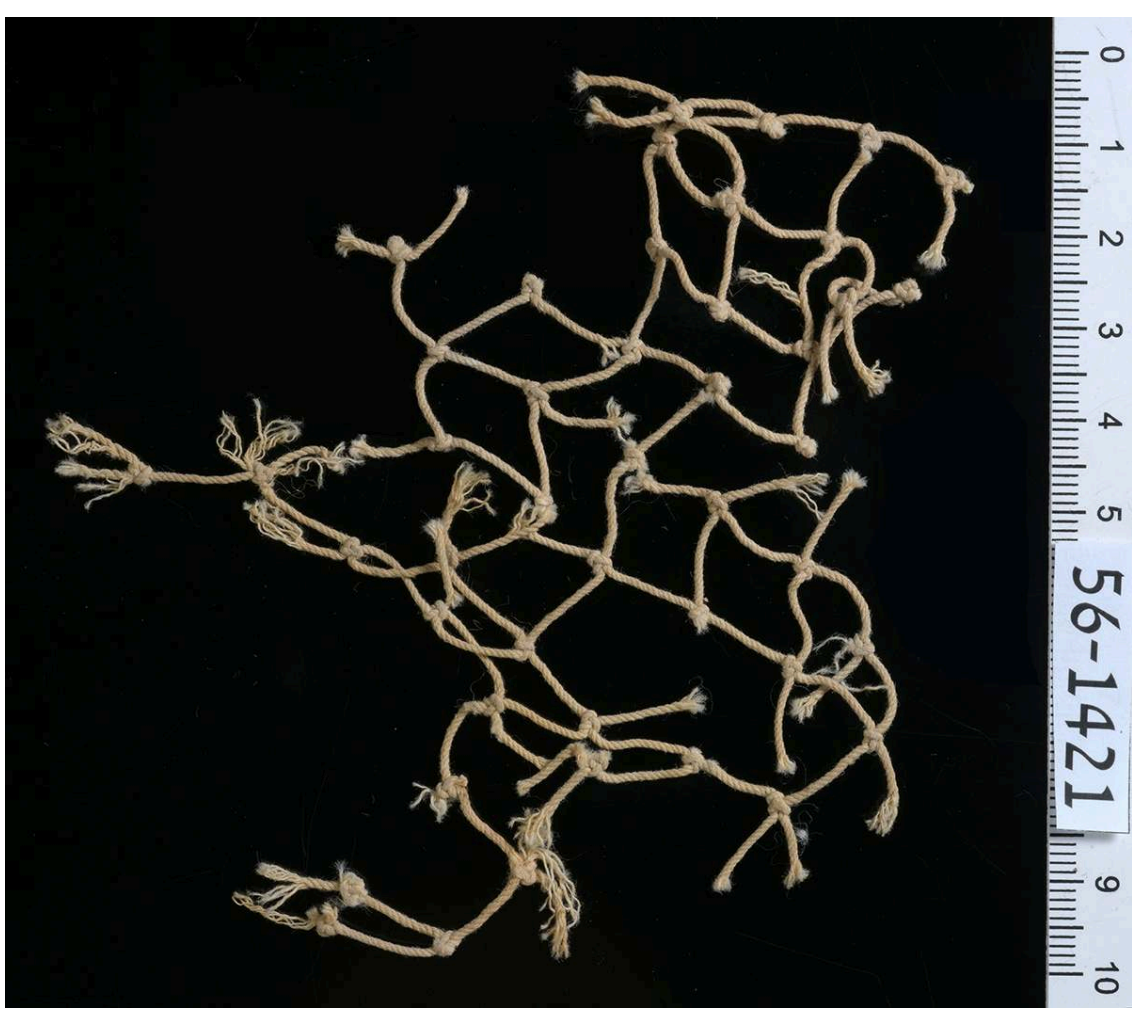

Clara Amit, Israel Antiquities Authority

\section{Byzantine period cotton textiles}

More linen than woolen textiles were found on Byzantine sites (174 out of 277 recorded pieces), probably because many excavated sites are burials and because linen was strongly favored in funerary context. Wool comprises 94 of the 277 Byzantine textiles, while 21 specimen were made of cotton.

15 'En Bogeq is a fort in an oasis located on the western shore of the Dead Sea, $13 \mathrm{~km}$ south of Masada (Gichon 1993 et 2000). Most of the textiles were found in the southeast tower, among domestic debris on the earth floor, and belong to the fourth phase of the site's occupation (624-635 CE). The inhabitants were probably of Christian faith. The fact that sha'atnez textiles (in Hebrew, wearing garments of mixed sheep's wool and linen, Shamir 2017a; 2017b) were found at 'En Boqeq is further evidence that the occupants of the site were not Jewish. 14 textiles (out of 167) are made of cotton. Three have a linen warp and a cotton weft ${ }^{2}$. All the cotton textiles are S-spun except for one, and weaving is always in tabby. Two were decorated with self-bands and several show colorful bands (Figure 3). Because the threads are exclusively S-spun, the authors suggested a local (or Nubian) origin (Sheffer \& Tidhar 1991: 22, 37). 
Figure 3: Cotton textile decorated with bands,'En Boqeq, Byzantine period, IAA no.94-9005

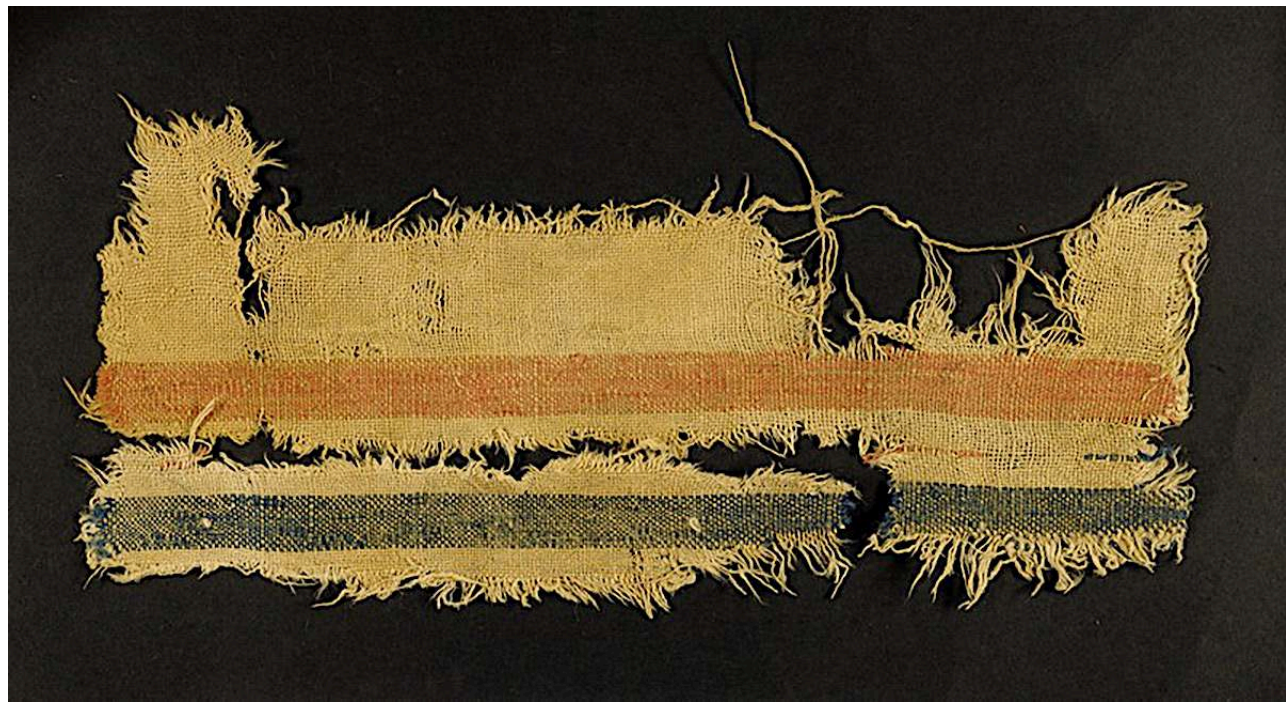

Clara Amit, Israel Antiquities Authority

16 Nessana is located $52 \mathrm{~km}$ southwest of modern Be'er Sheva. Most of the textiles were found in monks' tombs dated to the $5^{\text {th }}$ century CE (Colt 1962). Five cotton fabrics were found, on a total of 35 textiles. Three are made of Z-spun threads, and two show S-spun threads, while weaving is in tabby (balanced tabby, weft-faced and warp-faced tabby) (Figure 4). Two textiles are dyed: one in brown and one with some brown threads in the warp and some brown and blue threads in the weft. One textile is woven in a check pattern of white, tan and blue. Louisa Bellinger compared the texture of these textiles to other cotton fabrics from Yemen, with heavy warps and fine wefts (Bellinger 1962: 91, 98-99).

Figure 4: Cotton textile, Nessana. Byzantine period, IAA no. 1936-1445

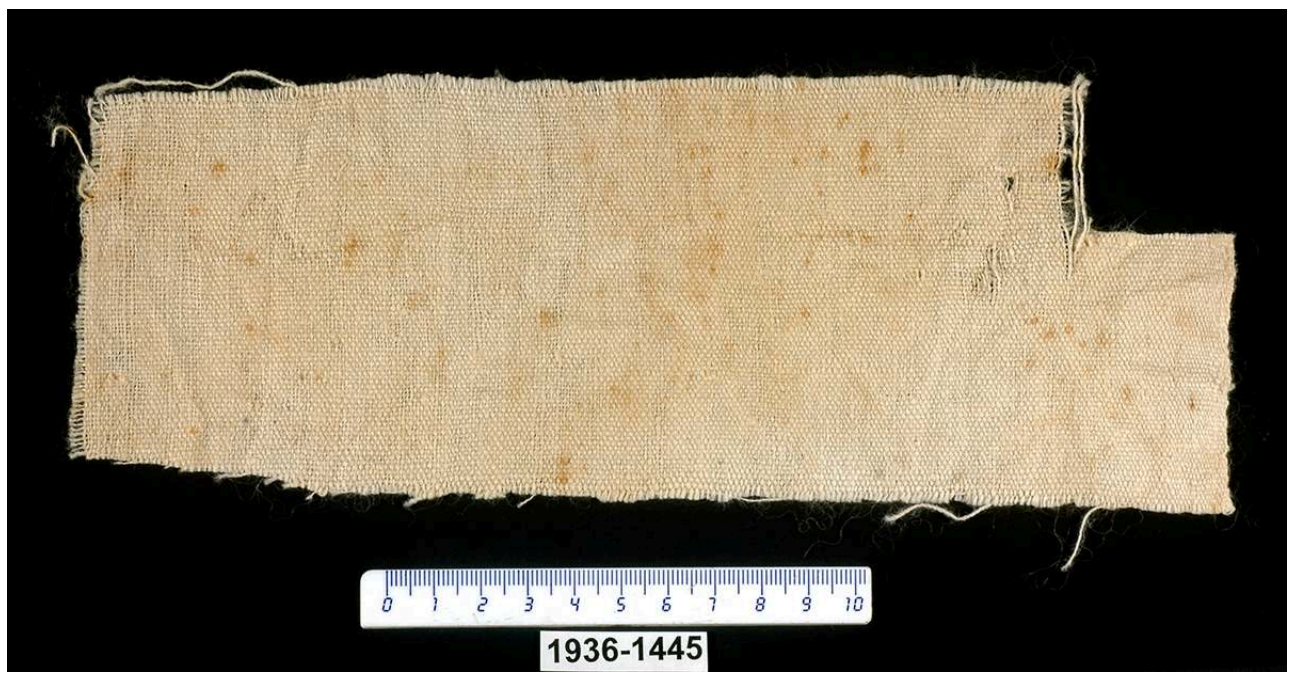

Clara Amit, Israel Antiquities Authority

17 Rogem Zafir was a way-station on one of the branches of the Spice Route connecting Petra and Gaza, and consist of several rooms built around a courtyard $(9.1 \times 9.35 \mathrm{~m})$ (Cohen 1991: 67). It is dated to the $4^{\text {th }}$ century CE and yielded two cotton fragments 
(Figure 5) out of the 23 textiles found. It is made of S-spun over-twisted threads, in plain weave, with a grid pattern of undyed cream, light brown and orange-red yarns. The orange-red threads are made of wool (Shamir 2007a: 271).

Figure 5: Cotton textile, undyed cream, light brown and orange-red grids, Rogem Zafir, Byzantine period, IAA no.94-9044

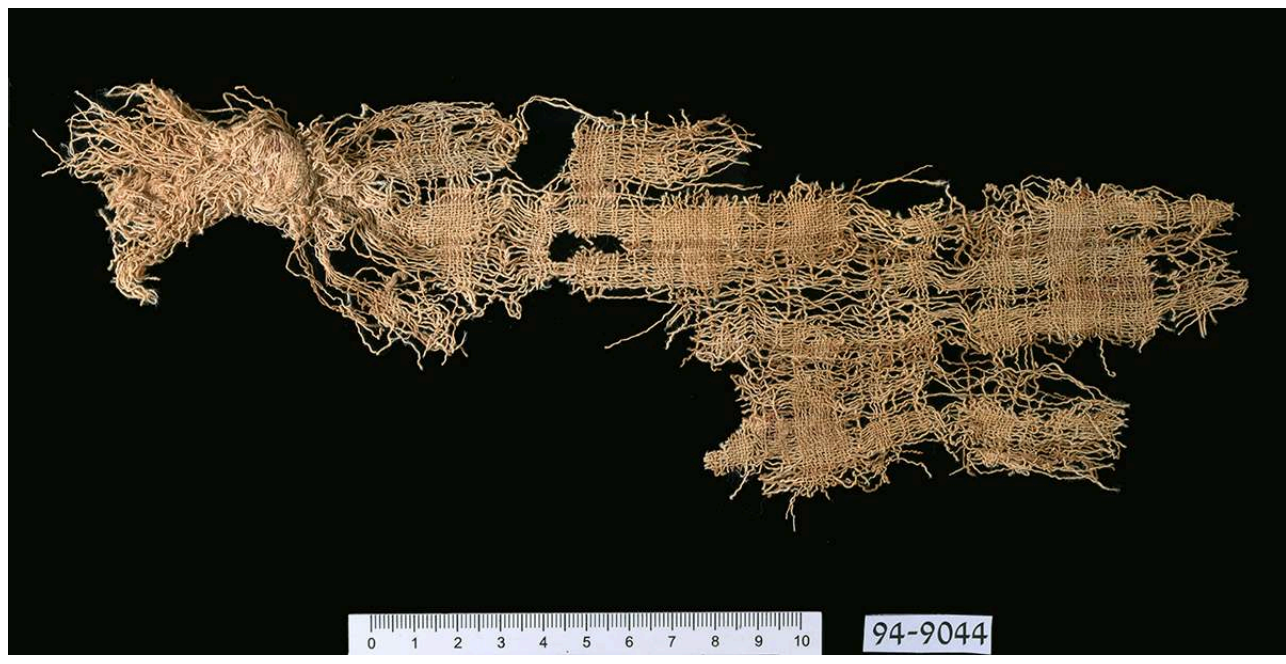

Clara Amit, Israel Antiquities Authority

Figure 6: Cotton textiles and spin direction in ancient Palestine during the Byzantine period $\left(4^{\text {th }}-7^{\text {th }}\right.$ c. CE)

\begin{tabular}{c|c|c|c|c|c|c}
\hline Site & \multicolumn{1}{|c|}{ Reference } & Total $\mathrm{n}^{\circ}$ of textiles & N of cotton textiles $^{\text {S-spun }}$ & Z-spun \\
\hline En Boqeq & Sheffer \& Tidhar 1991 & 167 & 14 & 13 & 1 \\
\hline Nessana & Bellinger 1962:91, 98-99 & 35 & 5 & 2 & 3 \\
\hline Rogem Zafir & Shamir 2007a:271 & 23 & 2 & 1 & 1 \\
\hline 'Avdat & Baginski. and Tidhar 1978 & 1 & - & & \\
\hline Archilais & Shamir 2007a:237 & 1 & - & & \\
\hline Be'er Sheva - Civic Center (burials) & Shamir 1999 & 2 & - & & \\
\hline Tell El-Ful (burials) & Shamir 2007a:237 & 5 & - & & \\
\hline 'En Gedi & Shamir 2007b & 17 & - & & \\
\hline Rehovot-in-the-Negev (burials) & Shamir 2007a:237 & 10 & - & & \\
\hline Jericho Roundabout & Shamir 2007a:237 & 1 & - & & \\
\hline Tell Sheva (burials) & Shamir 2007a:237 & 15 & - & & \\
\hline Total & & $\mathbf{2 7 7}$ & $\mathbf{2 1}$ & $\mathbf{1 6}$ & $\mathbf{5}$
\end{tabular}

\section{Early Islamic period cotton textiles $\left(7^{\text {th }}-11^{\text {th }} \mathrm{C} . \mathrm{CE}\right)$}

Wool was still dominant in ancient Palestine during the Early Islamic Period (160 specimens out of 378 textiles recorded), but cotton became almost as common as wool (161 out of 378 textiles, see Figure 7). Silk textiles were still very rare (3 out of 378).

19 Cotton fragments have been found at only three Early Islamic sites (Figures 7 et 8): 'En Evrona, 'En Marzev (Yahav), and Nahal Omer where a proportionally large number of cotton fragments were discovered (153 out of 251 textiles). They are mostly Z-spun and date to the $7^{\text {th }}$ century CE. 
Figure 7: Cotton textiles and spin direction in ancient Palestine during the Islamic period $\left(7^{\text {th }}-8^{\text {th }} \mathbf{c}\right.$. CE)

\begin{tabular}{c|c|c|c|c|c|c|c}
\hline \multirow{2}{*}{ Site } & Reference & Total $\mathrm{n}^{\circ}$ of textiles & $N^{\circ}$ of cotton textiles & S-spun & Z-spun & Z/S \\
\hline Deiran, Khirbet (Rehovot) & Shamir 2007c & 1 & 1 & & 1 & \\
\hline 'En Evrona & Shamir 2016b & 22 & 2 & & 1 & 1 \\
\hline En Marzev & Shamir 2016a & 57 & 2 & & 2 & \\
\hline Nahal 'Amram (copper mining) & Unpublished & 3 & 3 & & n.a. & n.a. \\
\hline Nahal 'Omer & Baginski \& Shamir 1995 & 251 & 153 (33 cataloged) & 8 out of 33 & 16 out of 33 & 9 out of 33 \\
\hline Nahal Shahaq & Shamir 1995 & 16 & - & & & \\
\hline Yotvata & Shamir 2007a:204-06 & 28 & - & & & \\
\hline Total> & & $378>$ & 161 & & &
\end{tabular}

\section{‘En Marzev ('En Yahav)}

Fifty seven textile fragments, most of them made of wool, and 10 small bundles of woolen fibers were uncovered at 'En Marzev settlement (Porath 2016). The site is dated to the Early Islamic period (late $7^{\text {th }} 9^{\text {th }} \mathrm{C}$. CE), a date confirmed by radiocarbon analysis (787-896 CE) ${ }^{3}$. Most of the textiles were found at Building $\mathrm{C}$, which is formed by rooms surrounding a large courtyard. One of the two cotton textiles is made in a balanced tabby with $18 \mathrm{Z}$-spun threads per $\mathrm{cm}$ in both systems (Figure 9). The weave is very delicate, with thin threads and a very open structure. It is white, decorated with red cotton bands (each $0.8 \mathrm{~cm}$ wide) alternating with shiny silk. The silk threads are S-spun and wound with disintegrated silver strips. Long fringes were preserved on $4 \mathrm{~cm}$, twisted Z2S2Z. Precious metal such as gold and silver were sometimes used to wound decorative threads for luxury fabrics, employed as diplomatic gifts between the elites through political and religious networks (Weiner \& Schneider 1989: 1). The presence of such a luxury item at 'En Marzev embodies the overall high quality of the textiles found at the site, in sharp contrast with Nahal 'Omer (see below). While the finds from 'En Marzev originated in structures abandoned in an orderly fashion, the finds from Nahal 'Omer originated in a waste dump, thus representing an accumulation of objects discarded over years of habitation (Shamir 2016a: 18). 
Figure 8: Location of Nahal 'Omer and nearby Spice Routes sites

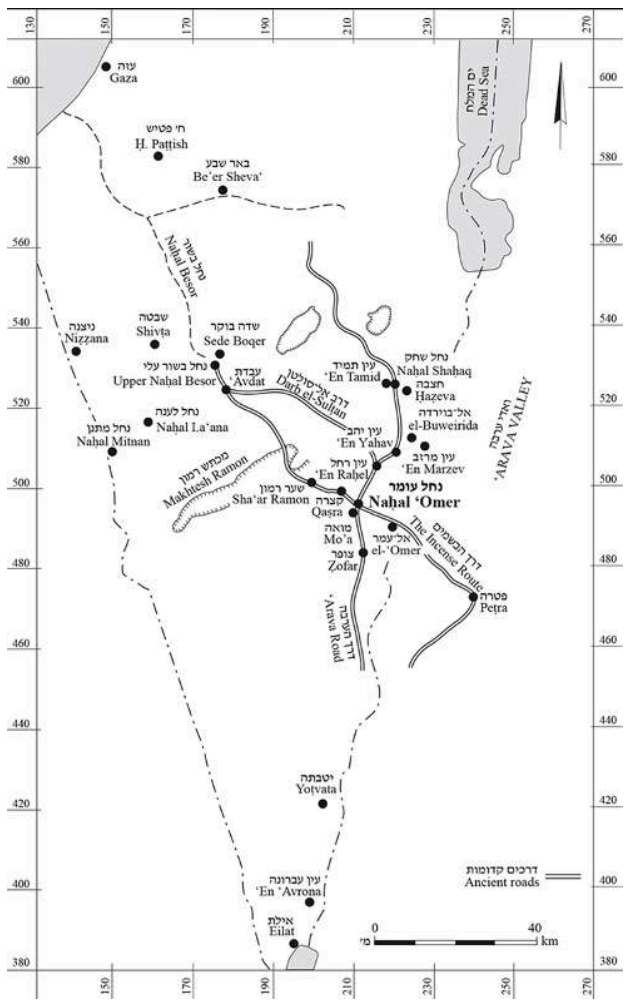

After Baginski \& Shamir 1995: 21

Figure 9: Cotton textile decorated with a band consists of cotton red bands alternating with shiny silk S-spun threads wrapped with metal strips that were disintegrated. 'En Marzev ('En Yahav), Islamic Period, IAA no. 2003-9055

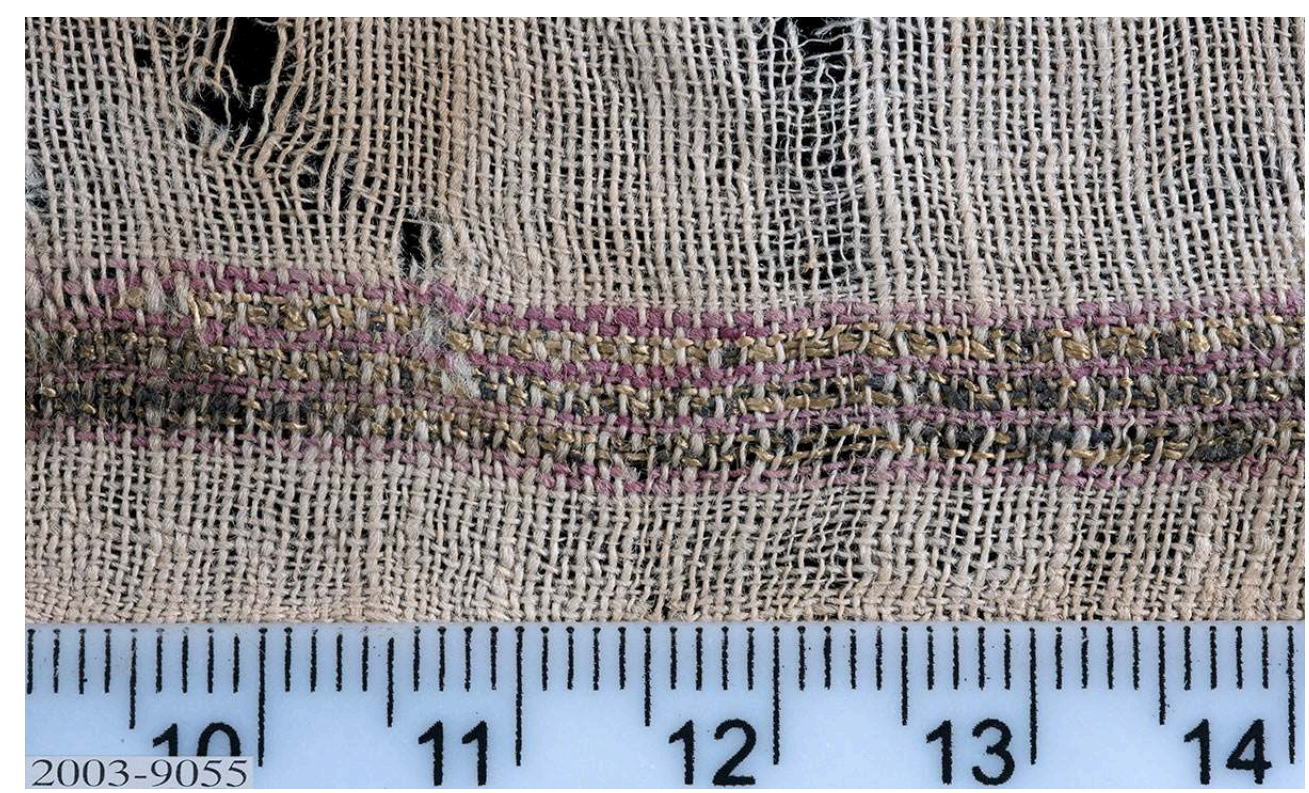

Clara Amit, Israel Antiquities Authority 


\section{'En Evrona}

During the early Islamic period ( $7^{\text {th }}$ century CE), 'En Evrona was a road and supply station on the important Hajj route, which connected North Africa to the Arabian Peninsula and the holy places of Islam (Porath 2016). Only two cotton textiles were found on the site. One of them is Z-spun in both systems, warp faced and dyed blue in the threads (Figure 10). Its hem is preserved and sewn with red, Z-spun threads in running stitches. The other fragment is a tabby with Z-spun faded red-and-blue warp threads, and S-spun red weft threads. The number of threads per centimeter varies in the warp from 24 to 25, and in the weft, from 11 to 19 (Shamir 2016b).

Figure 10: Blue cotton textile, 'En Evrona, Islamic Period, IAA no. 819480

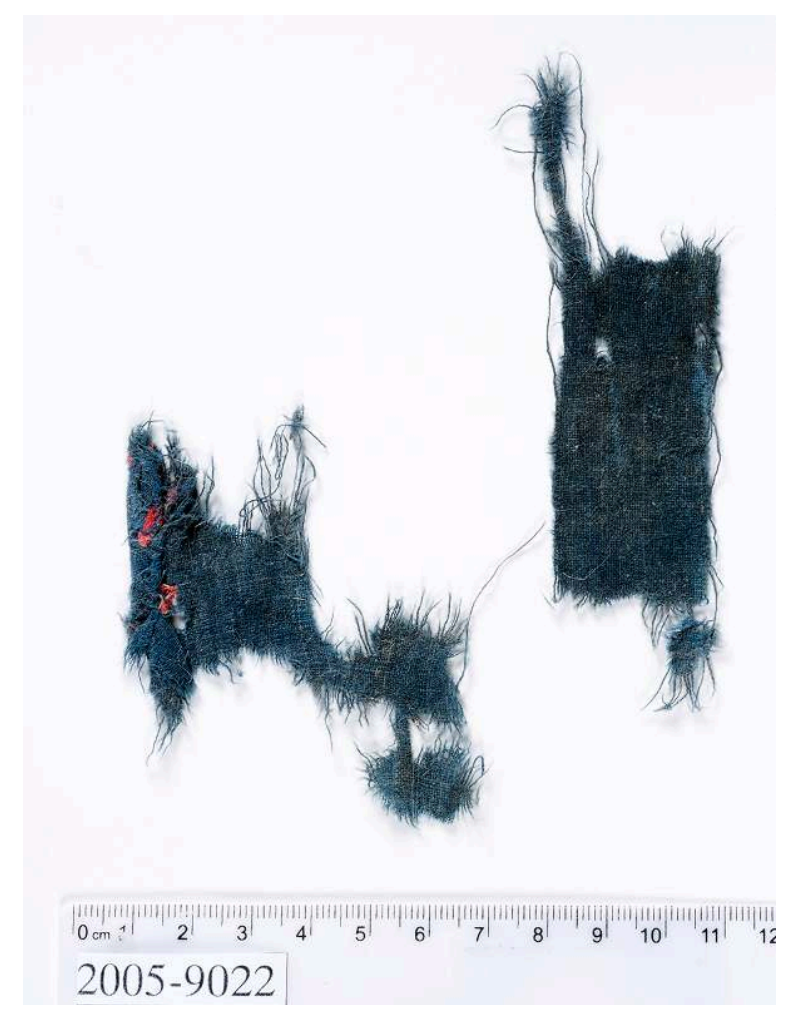

Clara Amit, Israel Antiquities Authority

\section{Nahal ‘Omer}

Nahal 'Omer (Figure 6) is located c. $40 \mathrm{~km}$ northwest of Petra on the western edge of the 'Aravah Valley, along a spring. It appears to have been a farming village on the Spice Route joining Petra, in the Edom Mountains of present-day Jordan, and the mercantile outlets on the Mediterranean Sea, notably Gaza and El 'Arish (Ben-Michael et al. 2018). Covering a surface of 0.1 hectare, the site is situated on the eastern bank of Nahal 'Omer, and includes the remains of 17 rectangular dwelling units, as well as a mosque, in use during the Early Islamic Period between 650 and 810 CE. The date of the material, provided by its archaeological context, has been confirmed by radiocarbon analysis (Carmi \& Segal 1995). Most of the textile material was discovered in middens (waste dumps) and many had been cut into small pieces. Few textiles were recovered from the remaining ruins of the buildings. 
The small number of textiles and other artefacts (including simple and poor ceramic vessels) indicate that the site was only used for a limited period of time corresponding to the Early Islamic period. It had been abandoned by its inhabitants when the route changed its path, moving away from Nahal 'Omer. Prior to this shift, it is probable that the village provided caravans with shelter, limited water, fodder, and other amenities, offering a welcome relief from the dangers of the caravans' roads.

In existence since the Nabatean period ( $4^{\text {th }}$ century BCE $-4^{\text {th }}$ century $\mathrm{CE}$ ), these routes also led to Egypt, to the Arabian Peninsula, to Yemen, to parts of the Persian Gulf and to the sea ports to India, as well as to Mesopotamia, Central Asia, and from there all the way to China (Baginski \& Shamir 1995). The caravans carried a variety of trade goods as well as spices, which were a major economic asset during the Roman, Byzantine and Early Islamic periods. The caravans were also used by pilgrims headed for Mecca. At the heart of such a dense trading network, Nahal 'Omer presents a very interesting and diverse material landscape.

\section{General observations of the textile finds}

25 The textiles display a remarkable variety of materials, techniques and dyes, suggesting diverse geographical origins. Most significant are a number of cotton fragments decorated in the warp ikat technique (Figures 11-13), which constitute the earliest documented occurrence of this type of cotton textiles anywhere in the world.

Figure 11: A fragment of the cotton warp ikat, Nahal 'Omer, Islamic Period, IAA no. 94-9048

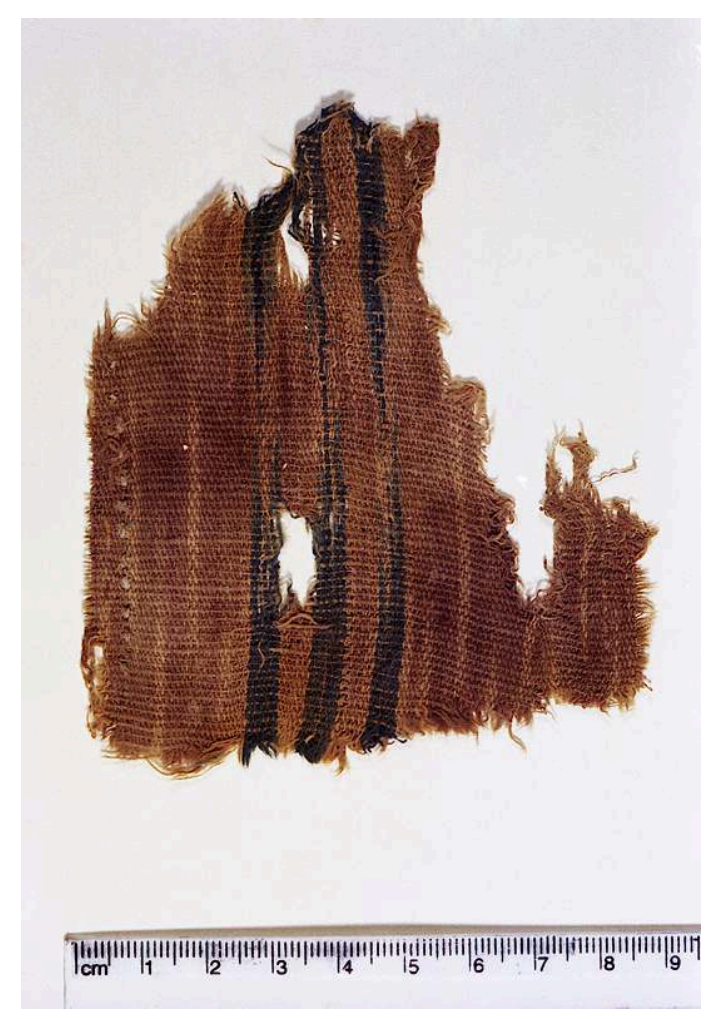

Clara Amit, Israel Antiquities Authority 
Figure 12: A fragment of the cotton warp ikat, Nahal 'Omer, Islamic Period, IAA no. 94-9065

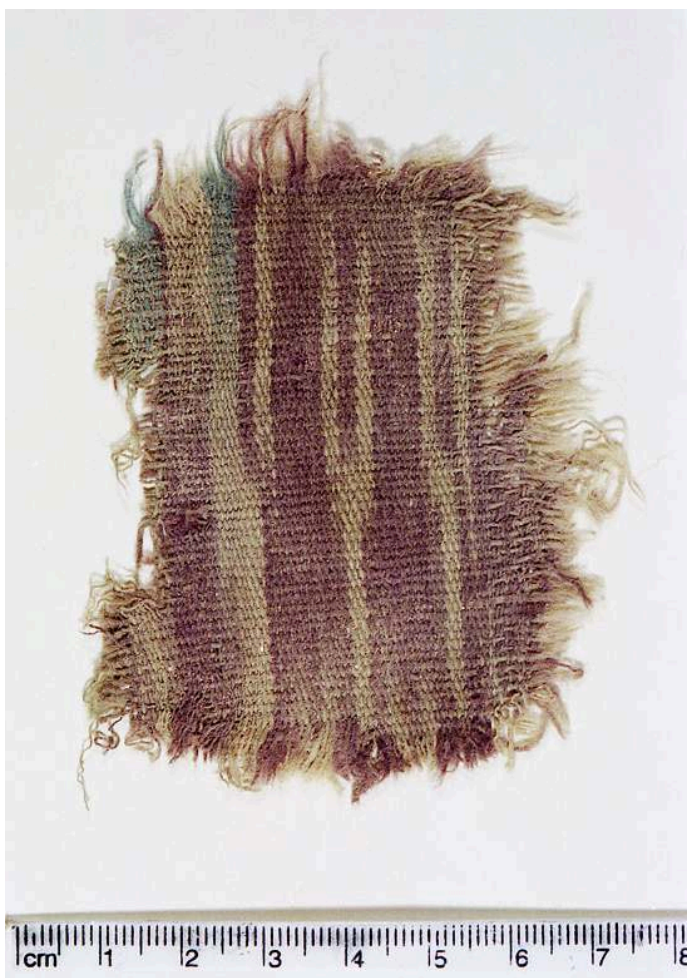

Clara Amit, Israel Antiquities Authority

Figure 13: A fragment of the cotton warp ikat, Nahal 'Omer, Islamic Period, IAA no. 94-9050

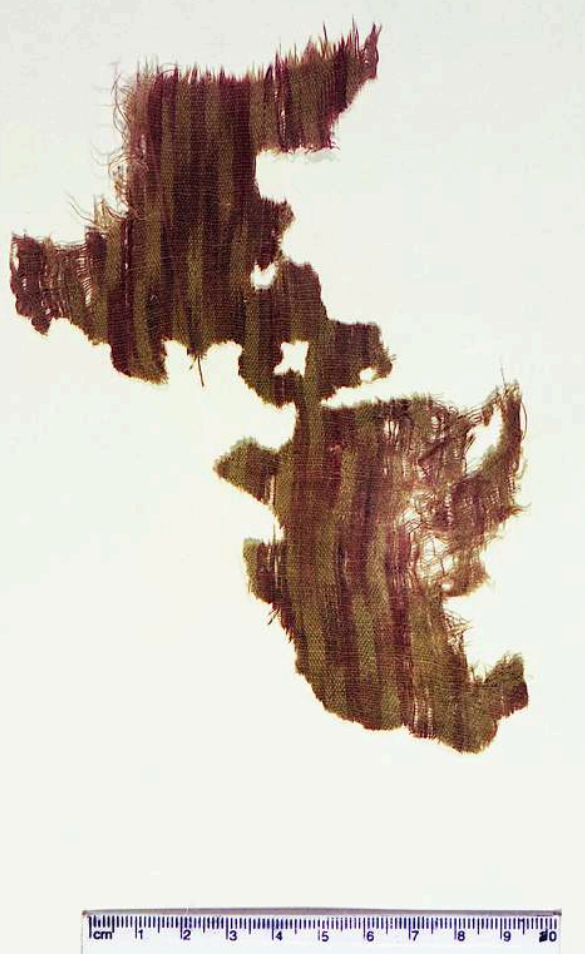

Clara Amit, Israel Antiquities Authority 
26 garments. The composition of the Nahal 'Omer assemblage is remarkable for its high proportion of cotton textiles - 153 out of 251 specimen - while this fibre is otherwise rarely found from this period. Sixteen textiles are made of Z-spun threads in both warp and weft direction; 9 are Z-spun in one direction and S in the other; 8 are S-spun in both directions. Some threads are over-twisted; one textile fragment even exhibiting a crepe-like appearance $\left(n^{\circ} 23^{4}\right)$ caused by the very tight twist of the yarns as well as by using two different yarns in the weft - one tightly Z-spun and the other very tightly Sspun, like that of the warp (the fabric has a density of 16 warps $x 24$ wefts per $\mathrm{cm}$ ). All the cotton cloths are in tabby weave: 1 textile $\left(n^{\circ} 19\right)$ is an extended tabby (half basket), 13 are warp-faced (e.g. $n^{\circ} 13$ ), 7 weft-faced, 8 balanced tabby (e.g. $n^{\circ} 6$ ), and 4 are tabby. Their weave density varies from medium to high ${ }^{5}$; the number of threads per $\mathrm{cm}$ varying in the warp from 6 to 30 , and in the weft from 7 to 24 .

One fragment $\left(n^{\circ} 29\right)$ has self-bands consisting of three weft threads used together in one shed. Eighteen of the cotton fragments are dyed: two are piece-dyed, one in monochrome blue $\left(n^{\circ} 26\right)$ and the other in monochrome red $\left(n^{\circ} 11\right.$, Figure 14). One $\left(n^{\circ} 17\right)$ has alternating blue and faded red weft bands on a beige warp. Three are check patterned: $n^{\circ} 4$ is a blue-green check with a reddish brown grid (Figure 15), and $n^{\circ} 5$ has beige (undyed), red, and blue warp stripes, the unevenly coloured weft alternating blue with beige (undyed) bands.

Figure 14: Cotton monochrome red, Nahal 'Omer, Islamic Period, IAA no. 94-9056

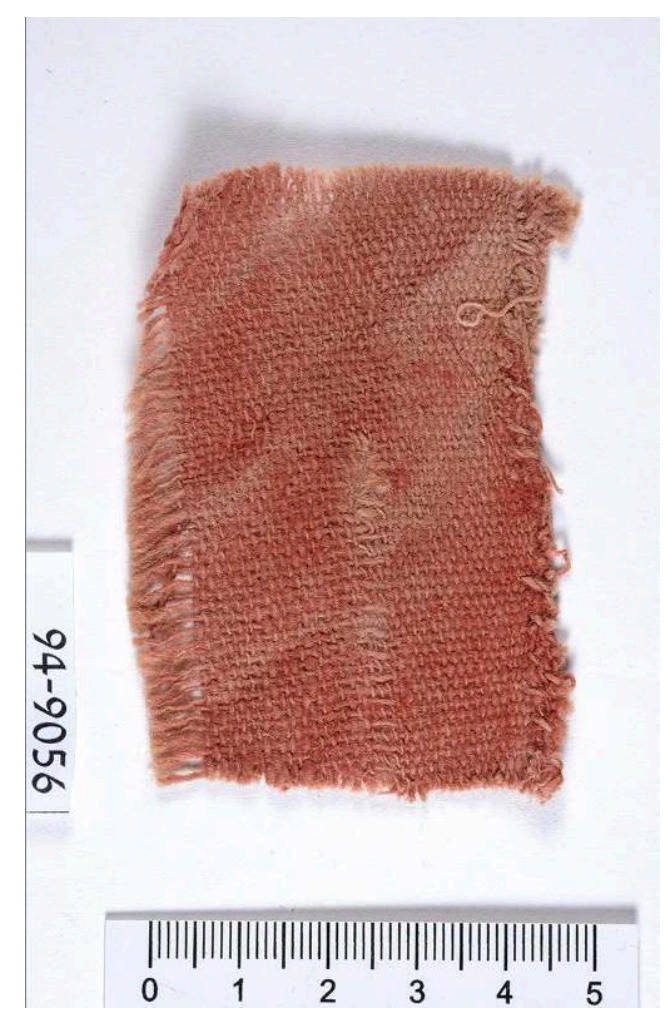

Clara Amit, Israel Antiquities Authority

Revue d'ethnoécologie, 15 | 2019 
Figure 15: Cotton checks, Nahal ‘Omer, Islamic Period, IAA no. 94-9051

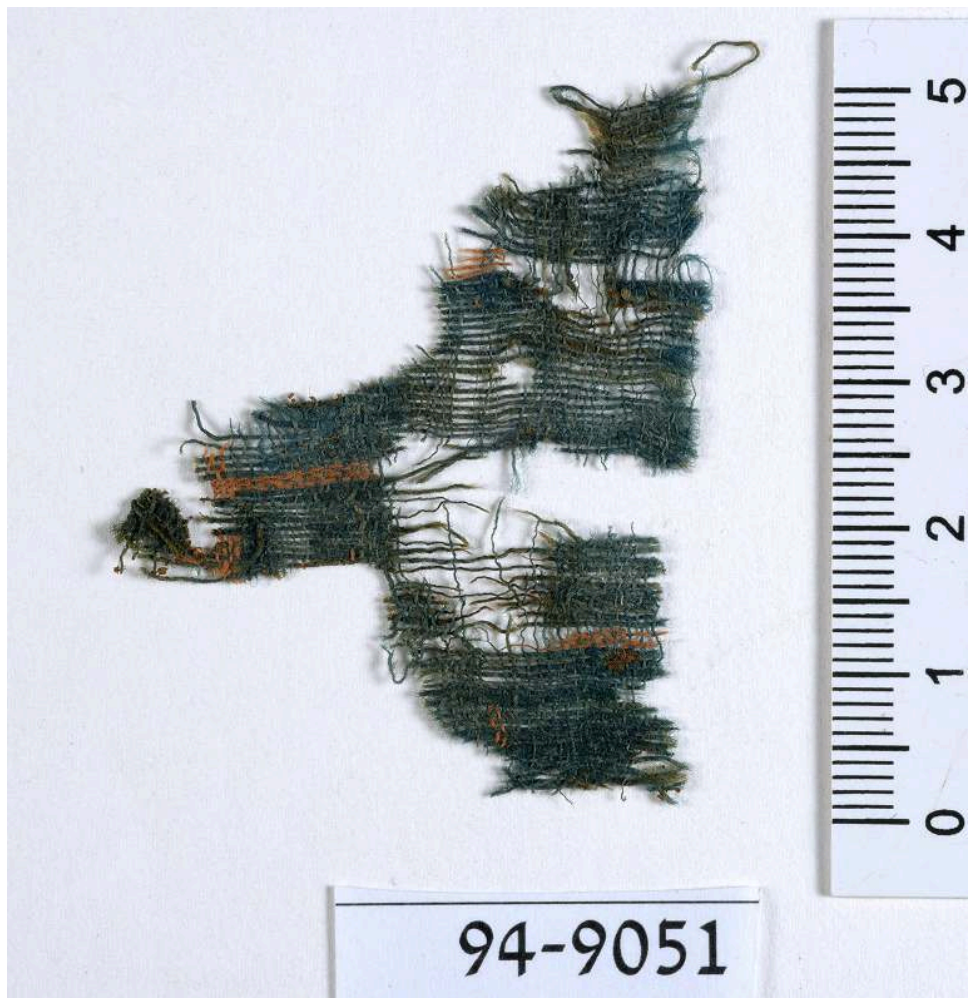

Clara Amit, Israel Antiquities Authority

Two of the cotton textiles are brocaded, such as one in blue-green ground with beige brocading $\left(n^{\circ} 30\right.$, Figure 16$)$. The pattern is unrecognizable because the fragment is very small. The other fragment $\left(n^{\circ} 9\right)$ is decorated with brocaded diamond motifs in red and cream on a checked ground of brown, red, and cream. $\mathrm{N}^{\circ} 8$ has a brown band on a beige ground. Finally, on two very small and poorly preserved fragments ( ${ }^{\circ} 16$ and 31 ) the patterns could not be recognised. 
Figure 16: Cotton with brocading Nahal 'Omer, Islamic Period, IAA No. 1994-9067

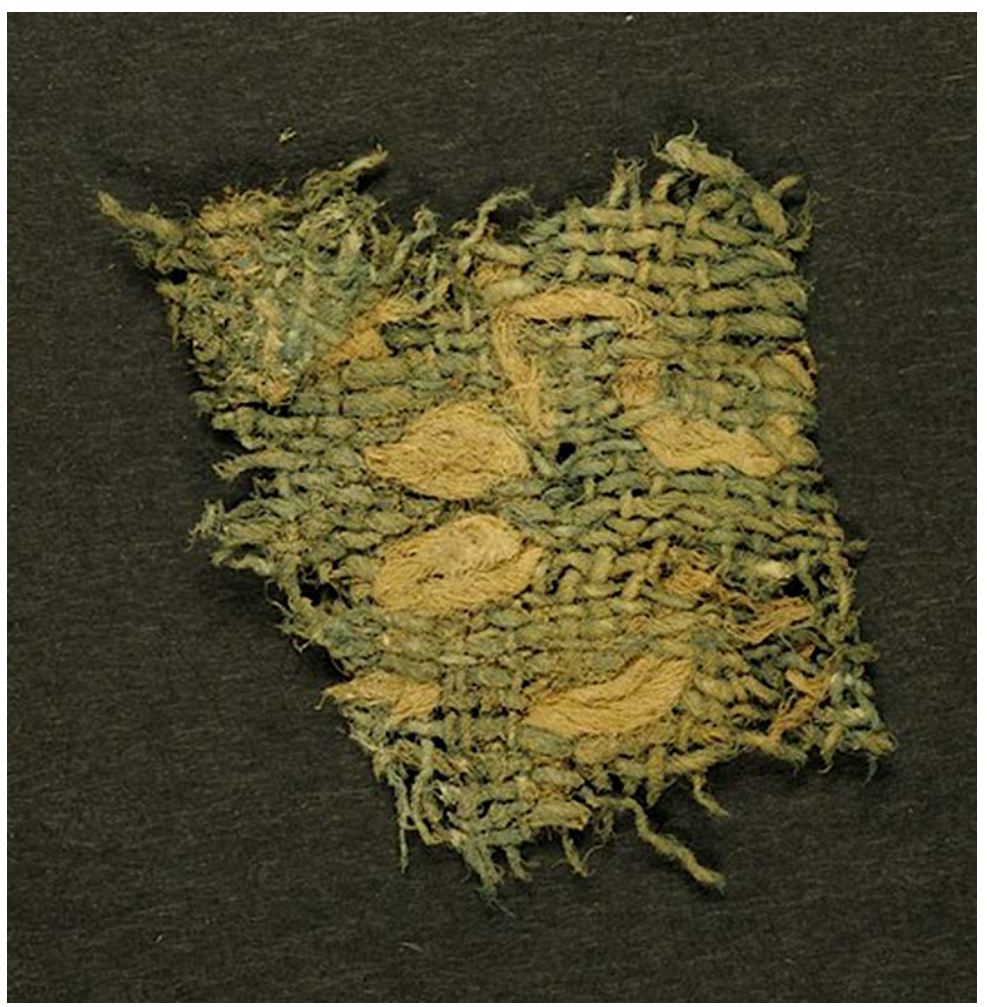

Clara Amit, Israel Antiquities Authority

\section{Zilu textiles}

29 A very distinctive type of furnishing textile has also been found at Nahal 'Omer: a zilu textile (pile-less) (Figure 17), which could have been used as floor covering in a religious building, in the same manner as the comparable Iranian zilus. The zilus are weft faced fabrics patterned by alternating floating wefts with cotton warps and wefts ${ }^{6}$. Zilu-looms were still in use in the modern era in the 1980s, notably in northeastern Iran in the workshops of Meybod, where they produced two-coloured carpets. Even in ancient times, this type of patterned textiles would only have been produced in specialised workshops (Ciszuk 2004: 112). Because of the loom's size and heavy weight, it was traditionally reserved to male weavers ${ }^{7}$. The specimen from Nahal 'Omer shows unusual technique and spin direction, different from the Levantine traditions, suggesting that compound weaves were not of local production and may have originated instead from Iraq, Armenia, or Iran (Mackie 1989: 86). Similar fabrics were for example found at Shahr-I-Qumis, an Iranian site dated to the $6^{\text {th }}$ century CE. 
Figure 17: Zilu textile made of cotton and wool, Nahal 'Omer, Islamic Period, IAA No. 1994-9081

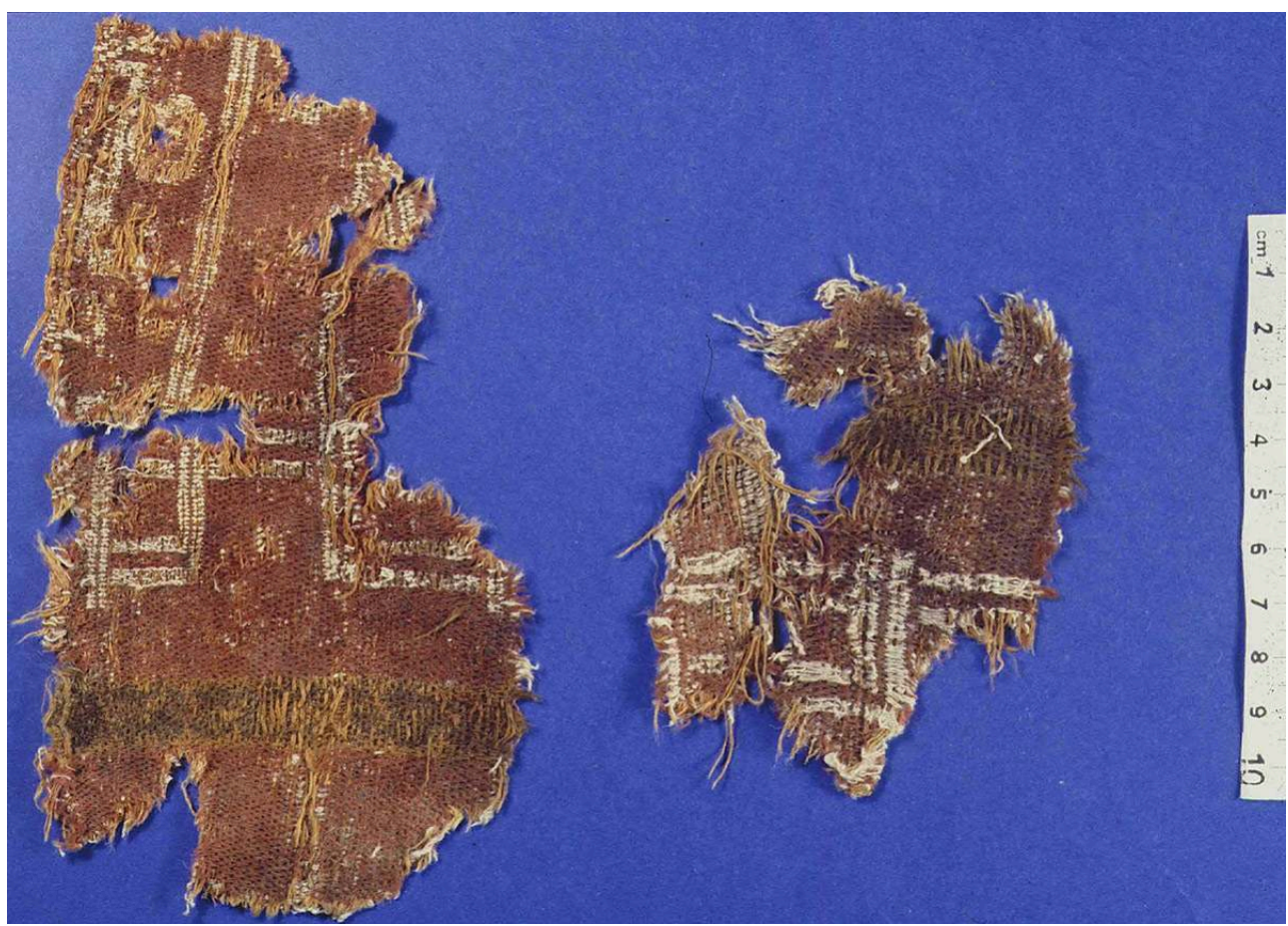

Clara Amit, Israel Antiquities Authority

\section{Ikat textiles}

Eight cotton fragments from Nahal 'Omer are decorated in a warp ikat technique (Shamir \& Baginski 2014. Figures 11-13). This technique forms a pattern by tying, and thus reserving, portions of the yarn - either warp, weft, or both - before dyeing. When dyed, dried, and unwrapped, the areas under the ties have stayed the original colour. The precision of the wrapping thus determines the clarity of the design. Ikat techniques are still practised today, for example in India and Uzbekistan, and it continues to inspire modern designers. In warp ikat, only the warp threads are reserved in this manner; the weave structure of the fabric is warp-faced tabby: the greater the number and the closer the spacing of warp elements in relation to weft, the more the warp will tend to conceal the weft. If the warp elements hide the weft elements completely, the fabric is said to be warp-faced. Weavers who need more precise patterning use warp ikats, where they can see the pattern on the loom even before starting to weave the weft in. This intricate technique requires particular expertise in preparing the warp, while the simple weave can be performed by less skilled persons.

31 At Nahal 'Omer, the ikat textiles are all warp-faced, exhibiting 14-28 warp threads per $\mathrm{cm}$ for 9-14 weft threads per $\mathrm{cm}$. The warp ikat threads are coloured in blue, brown, cream, reddish-brown, red, cream and tan, or combinations of these colours, and dyed with madder (reddish brown and brown) and indigo (blue) (identified by Z. Koren, in Baginski \& Shamir 1995: 23). Technically, the madder (Rubia tinctorum) and indigo dyes could have been produced in both India and ancient Palestine. The patterns consist of "feathers" and/or lozenges. All the ikat cloths at Nahal 'Omer show Z-spun threads, while other cotton textiles from the site are S-spun, according to local traditions developed for millennia in the region. The Z-spun yarns of the ikat cloths, as well as 
their unusual patterns, are strong indications of their foreign origin and argue for their importation to ancient Palestine. Because of the complexity of their dyeing techniques, $i k a t s$ have always had a high added value and have been used as status symbols, making these fabrics prime candidates for the textile trade.

The term ikat is a derivative of the Malay-Indonesian word mengikat, meaning 'to tie, to bind'. It is possibly related to the Semitic root 'qd (Bühler 1972: 31), which carries a similar meaning, and was for instance used in the biblical narrative of the "binding of Isaac" (Genesis 22:9) ${ }^{8}$. The term could have been introduced to the Far East by Near Eastern textile merchants. Interestingly, traces of ancient ikat textiles have been found at the two ends of this linguistic and trading route: ikats resembling those discovered at Nahal 'Omer are depicted in the cave paintings of Ajanta, in India, dated to the Vakataka Period (late $5^{\text {th }}-6^{\text {th }}$ c. CE, caves 1 and 17. Sivaramamurti 1977). Among the courtiers and ladies represented in the palace of Prince Siddartha, many wear wraps with flame-striped patterns, strongly reminiscent of $i k a t$ patterns (Zhao \& Wada 2014).

Except the ikats from Nahal 'Omer, the earliest known cotton ikats were discovered in Egypt, at Fustât (Bühler 1972, I: 23). They are decorated with woven-in inscriptions, dating the textiles to the $10^{\text {th }}$ century $\mathrm{CE}$ and indicating their probable origin in the Tiraz workshops of the Yemenite town of Sanaa. The fragments from Nahal 'Omer resemble the Yemenite ikats in patterns, material (cotton), and spin direction (Z-spun yarns), but not in the thread counts: the Yemenite productions are much finer, with $\mathrm{c}$. 30 warp x 14 weft threads/cm, versus the c. 14-28 warp x 9-14 weft threads in Palestine.

The above cited sources suggest that the cotton ikats from Nahal 'Omer may have been produced in either India or Yemen, where we found a commonality of design and colors. The technique itself was born in India before it spread both west and east via the trade roads to China and the Middle East. The Chinese specimen often exhibit threads made of precious silk. The Nahal 'Omer examples constitute however the earliest warp ikat textiles made of cotton. This innovation may be related to the greater development of trade ties between the Levant and the Far East - with Persia, India, and China - undertaken in the wake of the Arab conquest. More common in these regions, cotton then started to play a more central role in the agricultural and trading economies of the Middle East (Watson 1983: 31).

\section{Late Islamic period and medieval period cotton textiles}

\section{Textiles from the Judean Desert caves}

The Judean Desert (cf. Figure 1) is a desert in modern Israel and the West Bank territories, which lies east of Jerusalem and descends to the Dead Sea. Hundreds of artificial and natural caves were found across its landscape, in which archaeologists discovered many organic artefacts such as textiles, basketry, and cordage, exceptionnaly well preserved due to the arid climate (Patrich et al. 1988-1989). The hills around Jerusalem acted as a rain shadow, creating a local microcosm with both extremely low rainfall and low relative humidity. The objects cover the entire span of historical occupation, from the Neolithic to the medieval period, all the way to the modern times, as the caves were very frequently used for living, burials, and refuge. As such, the caves have been key repositories for organic artifacts for thousands of years and offer an excetionnal body of ancient textiles. 


\section{Cave III8 in Lower Wadi el-Makkuk (Figure 18)} $(1 / 206 / 20)$ is a faded blue balanced tabby with Z-spun warps and wefts (12 threads per $\mathrm{cm})$, the other $(3 / 243 / 5)$ is an undyed cream tabby, also with medium tight Z-spun warps and wefts ( $17 \times 14$ threads per $\mathrm{cm}$ ). The last is folded and sewn, with a protruding strip, its edge knotted to form a button. This fragment resembles a textile discovered in Qasr al-Yahud, dated by radiocarbon to the $9^{\text {th }}$ century CE (Shamir \& Baginski 2002).

Figure 18: Wadi el-Makkukh, general view

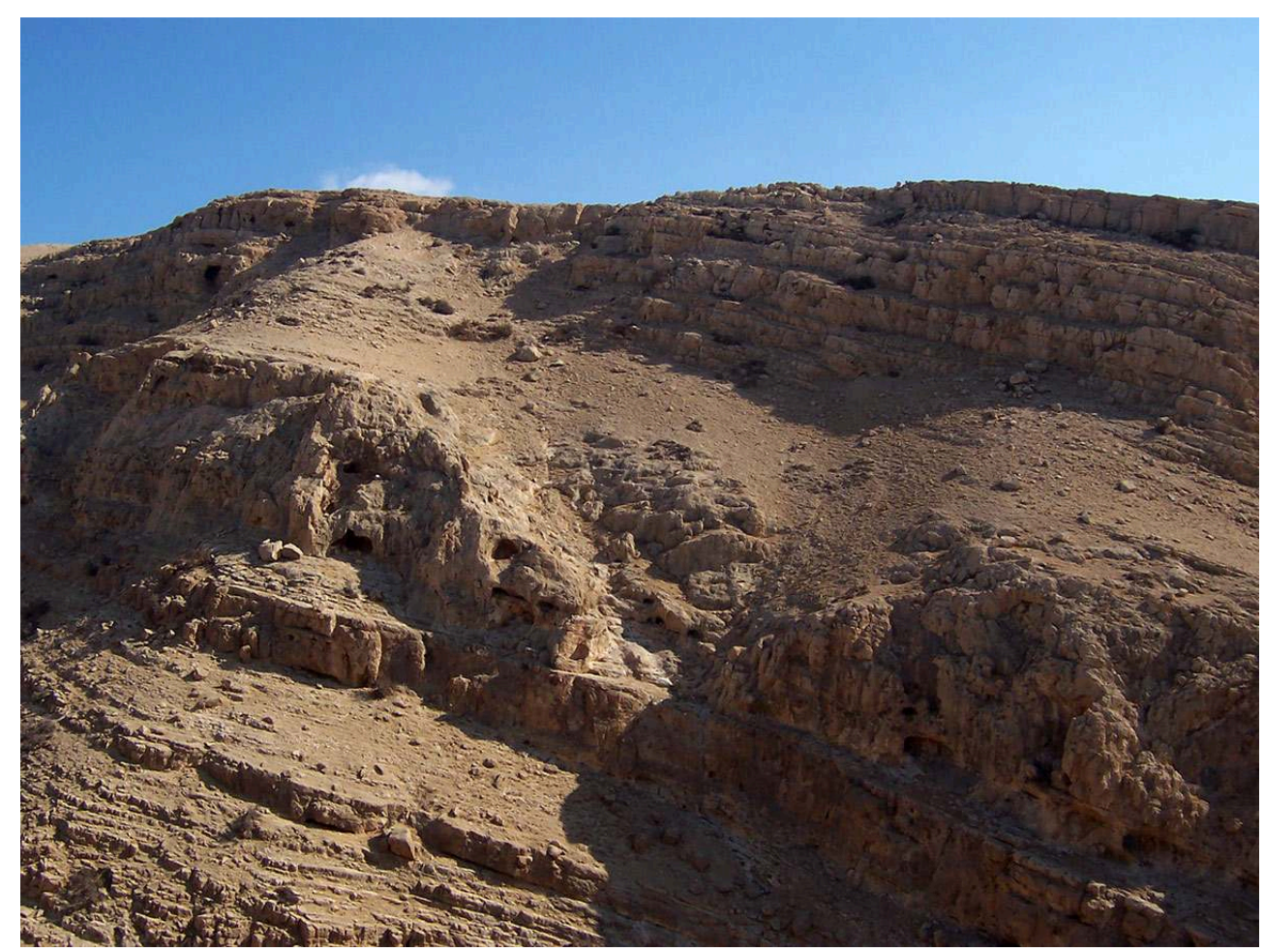

Photo Roi Porat

'Ein Far'ah, Cave 11 (Patrich 1984:62)

Textile $\mathrm{n}^{\circ} 3$ is made of cotton and has $\mathrm{S}$ and Z-spun threads in the warp and Z-spun threads in the weft (Figure 19). It is cut in a strip and knotted at the edge, and decorated with blue and faded pink stripes. Another textile $\left(n^{\circ} 31\right)$ is made in tabby weave and has $\mathrm{S}$ and $\mathrm{Z}$-spun threads in both directions. It is a cut strip decorated with blue stripes and check pattern (Shamir \& Schick forthcoming). 
Figure 19: 'Ein Far'ah, Cave 11, Medieval period cotton with S and Z-spun threads in the warp and Zspun in the weft (No. 3)

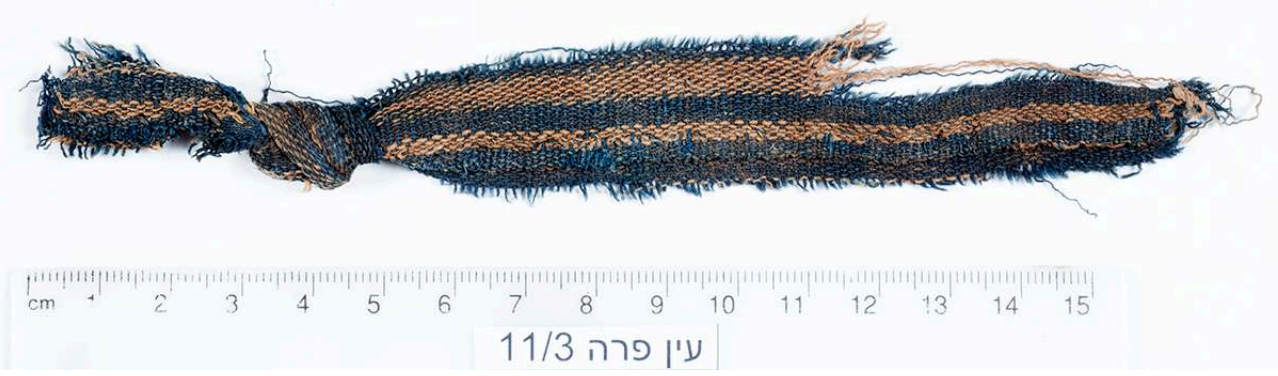

Clara Amit, Israel Antiquities Authority

\section{Makkukh-Qarantal Cliff, Cave 1}

Patrich's excavations at Qumran Cave 11 (Patrich 1994: 93) are made of cotton (Figure 21). They are similar to cotton textiles of the medieval period found in other Judean caves, their date verified by radiocarbon analysis (Sukenik et al. forthcoming, Taylor et al. 2005). with S-spun threads, while the weft is made of Z-spun cotton of larger diameter. The piece is woven in tabby, of an undyed cream color, and is made of three fragments of the same textile stitched together with a cotton S3Z sewing thread in a run-and-fell technique (Shamir \& Schick forthcoming).

The presence of a linen warp and a cotton weft in the same textile is common in the medieval period. This type of textiles was discovered in the contemporary Cave 38 $\left(9^{\text {th }}-13^{\text {th }}\right.$ C. CE) (133 examples out of the 768 textiles, Shamir \& Baginski 2013); as well as in Qarantal Cave V/49 (4 examples, Shamir \& Baginski 2002: 246). They are also reported in a small number at Quseir al-Qadim (mid-13 ${ }^{\text {th }}$-late $14^{\text {th }}$ century CE; Vogelsang-Eastwood 1982: 286).

\section{Makkukh-Qarantal Cliff, Cave 11}

Five cotton textiles are dated to the Roman period, one to the Byzantine period, and two to the medieval period. Textile $n^{\circ} 4$ is worth mentioning: it is another example of a mixed cotton and linen textile, with an S-spun linen warp and a Z-spun cotton weft. It is similar to the previously described fabric from Cave 1, and to the textiles from Cave 38. Once again, the linen threads are noticeably thinner than the cotton threads (Shamir and Schick forthcoming).

\section{Qumran Cave 11 (Figure 20)}

Eleven textiles, amounting to $6 \%$ of the total corpus collected during de Vaux's and (1) 
Figure 20: Qumran, Cave 11, general view

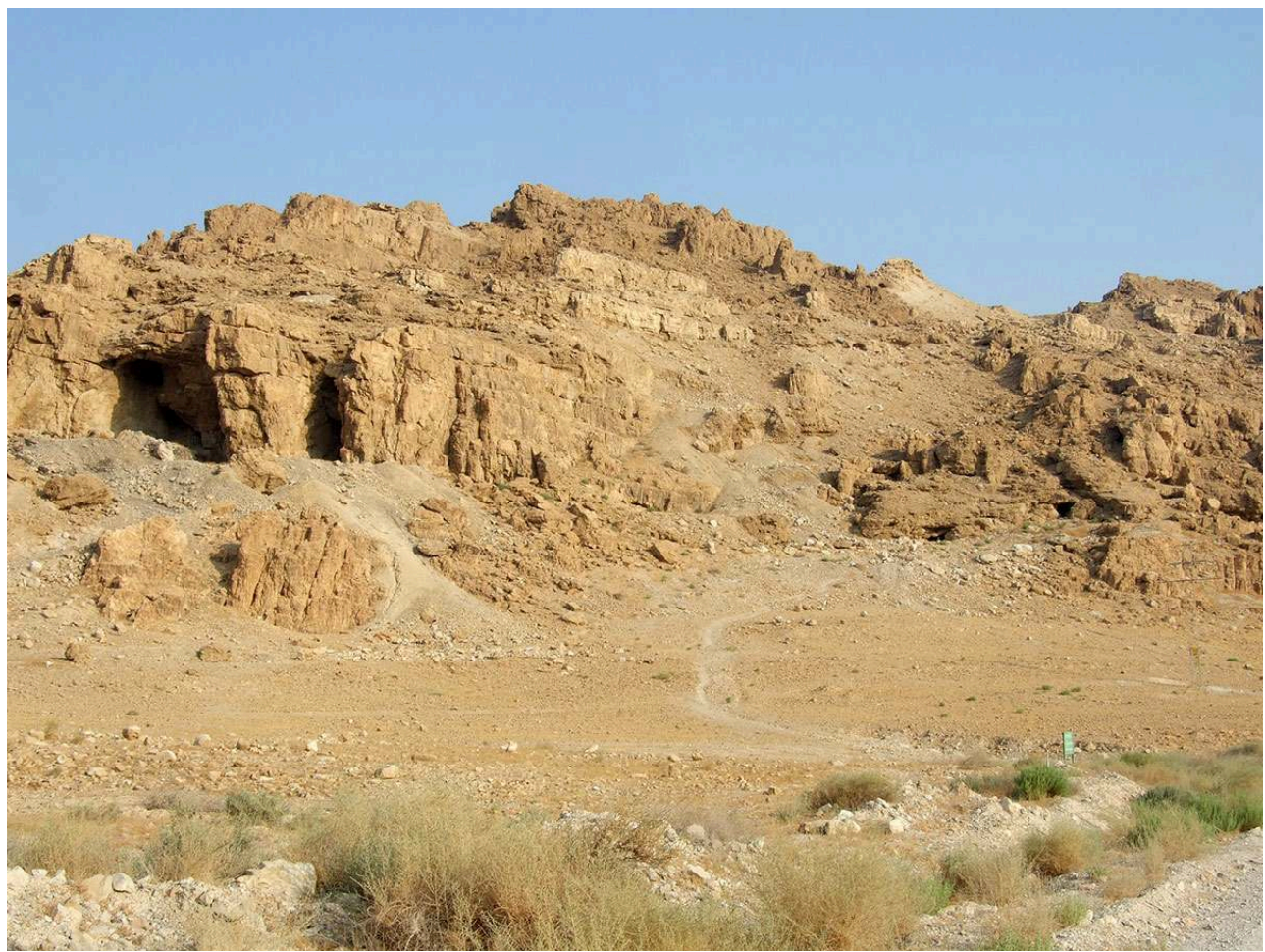

Photo Roi Porat

Figure 21: Qumran Cave 11 D. 097

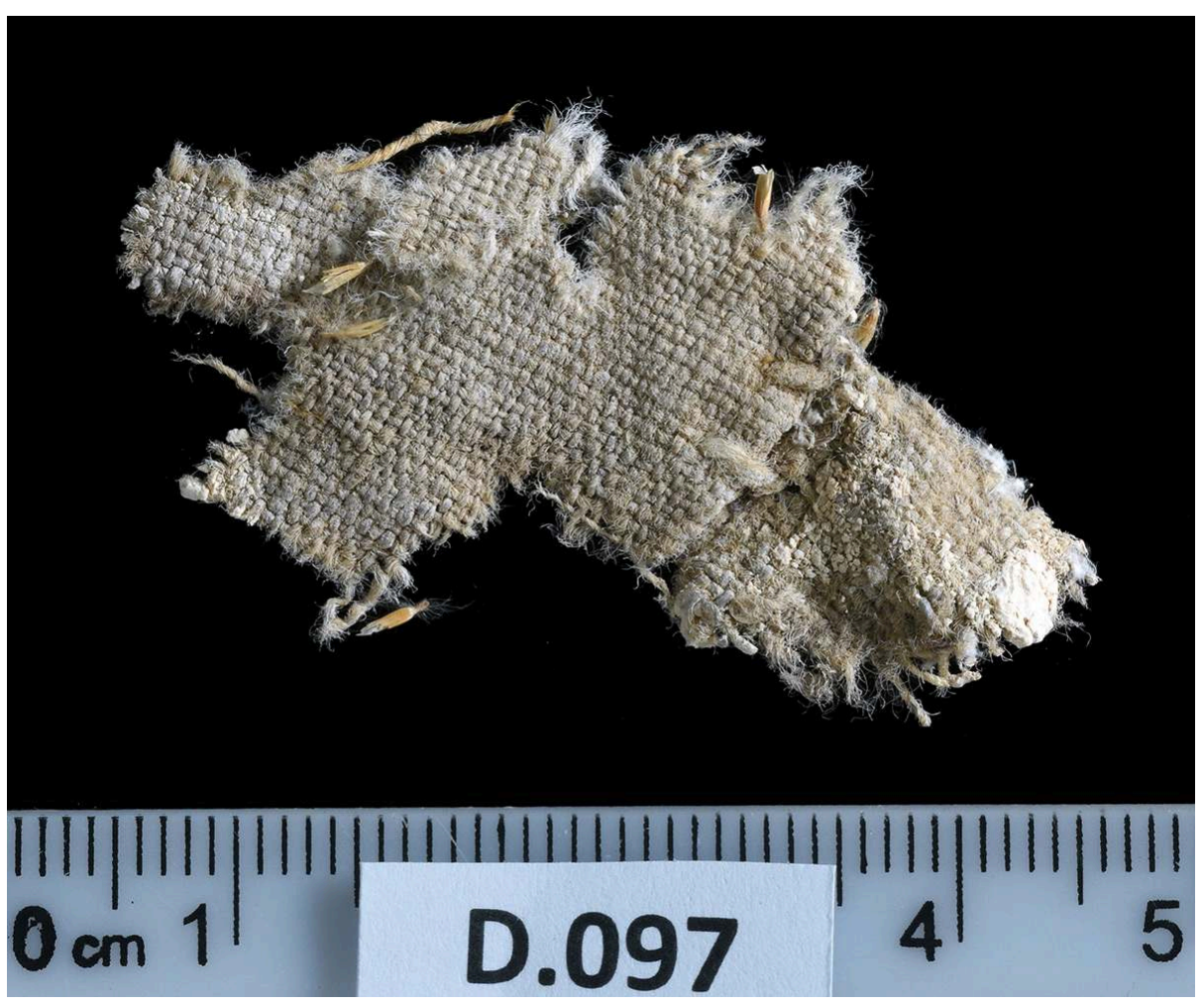

Clara Amit, Israel Antiquities Authority 


\section{Qasr el-Yahud}

42 A very special group of cotton textiles, including garments and shrouds, has also been discovered at Qasr el-Yahud, a site dated to the $8^{\text {th }}-9^{\text {th }} \mathrm{C}$. CE and situated on the west bank of the Jordan River, near Jericho (Figure 22). At the end of the $15^{\text {th }}$ century, the pilgrim Felix Fabri described the pilgrimage processions on the banks of the river, where the pilgrims prayed and dipped themselves in the waters, dressed in special clothing brought particularly for this purpose from their homeland (Gal 2011: 15). Believed to be the site of Jesus's baptism, Qasr el-Yahud is still regularly visited by thousands of pilgrims and faithful Christians wishing to receive the sacraments in this holy place.

Figure 22: The vicinity of Qasr el-Yahud

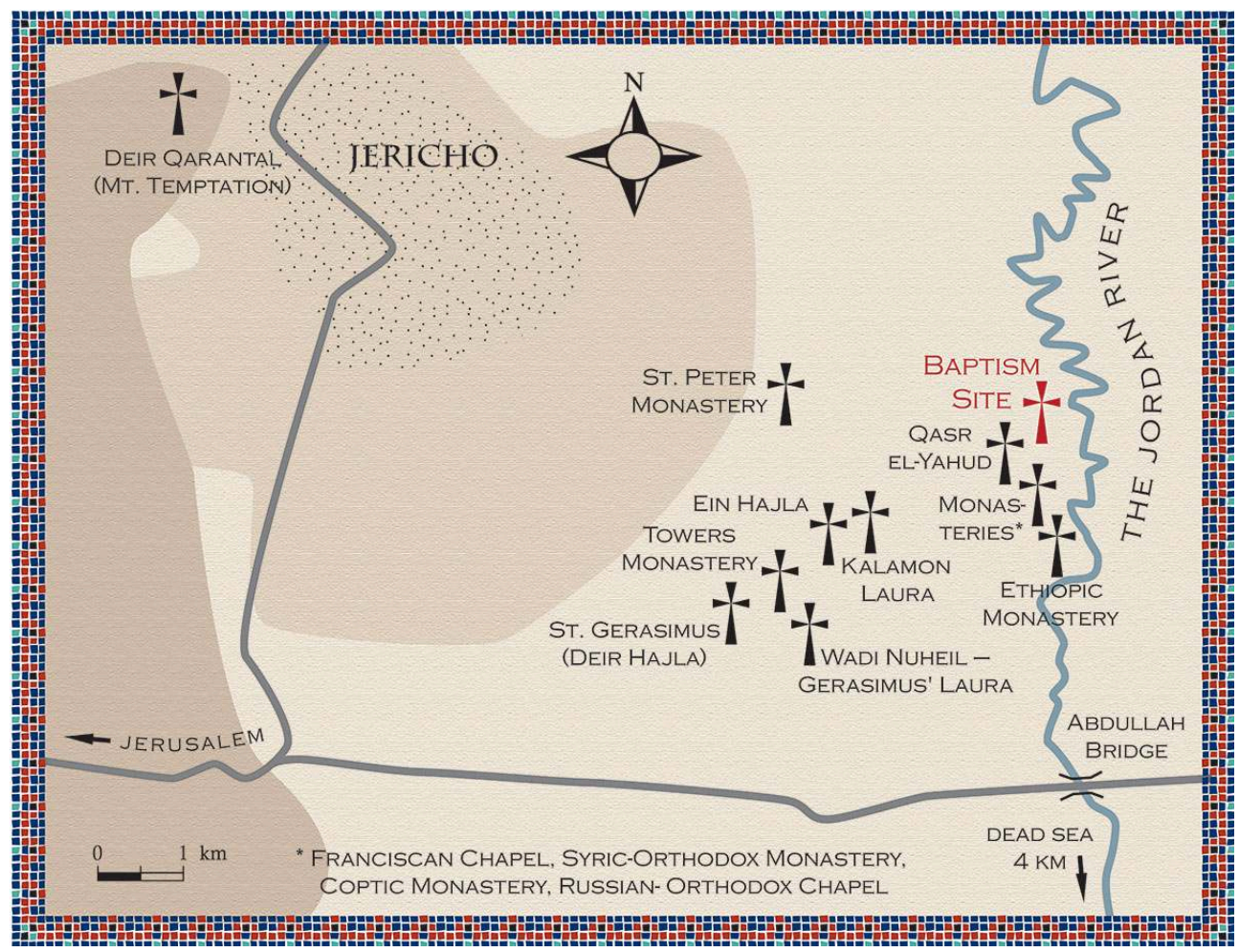

Map (CDina Shalem, Ostracon, Israel Nature and Parks Authority

In 1983, rescue excavation was carried out at Qasr el-Yahud under the supervision of anthropologist Joe Zias. A mass grave of around 300 men, women and children was discovered at the site during road constructions, which caused the destruction of c. $90 \%$ of the inhumations. 34 skeletons managed to be retrieved and kept. They represent a hospital population, exhibiting severe signs of tuberculosis, leprosy, and facial disfigurement cases. A concentration of such rare conditions isn't surprising at this location, as critical patients could travel enormous distances, attracted to the site in the hope of washing away their illness. The anthropological study of the skeletons and structural analysis of the skulls showed that these individuals may have come from Egypt and/or Nubia (Dauphin 1996: 55, Zias 2002: 264-266 and pers. comm.).

Some of the burial customs at this site, such as placing seeds from the Egyptian balsam tree (Balanites aegyptiaca) in the hands of the deceased, conform to known Egyptian 
traditions (Zias 2002: 264). The same seeds have been found in ancient tombs at Gizeh, Thebes, and various other sites in Lower and Upper Egypt. Different parts of the balsam tree were also traditionally used to treat a wide range of illnesses, which makes their presence in Qasr el-Yahud all the more meaningful (Amar \& Serri 2004:122-123, Amar \& Shamir 2013, Zias 2002).

Dr. Robert Janaway and his students from Bradford University cleaned and treated the textiles, and we catalogued them together. Radiocarbon dating made by the Weizmann Institute of Science on one of the textiles indicated a chronological bracket between the $8^{\text {th }}$ and the $9^{\text {th }}$ C. (787-877 CE). Maybe less accurately, a wood sample (RT-656) gave the date of 506-880 CE (Carmi 1987: 105).

Eighty-five textiles out of 250 fragments are made of cotton in both systems. The spin direction (Figure 23) is mostly S-spun in the warp and Z-spun in the weft, which is rather unusual (normally, the $\mathrm{Z}$ and S-spun threads are of different fibres, i.e. linen and cotton). The cotton fabrics are woven in tabby, usually in medium or dense weave (Emery 1966: 11-12). Simple tabby and its variations are the only types of weave attested at Qasr el-Yahud, in sharp contrast with the rest of the textile production from the Byzantine period onwards, which exhibits a more diverse and complex technical repertoire. All cotton textiles are undyed (cream or beige) expect for three specimen which are faded blue, and four are decorated with selfbands. Two pieces are preserved selvedge to selvedge, indicating the original width of the loom: $\mathrm{n}^{\circ} 13.1$ is $43 \mathrm{~cm}$ wide and $\mathrm{n}^{\circ} 14.4$ is $23 \mathrm{~cm}$ wide (Figure 24). The use of the textiles is varied and includes tunics, head coverings, bandages and shrouds.

Figure 23: Quantities of cotton textiles according to spin direction (in both warp and weft) at Qasr el-Yahud

\begin{tabular}{c|c} 
Spin Direction (warp/weft) & Number of textiles \\
\hline S/S & 32 \\
\hline Z/Z & 18 \\
\hline S/Z & 34 \\
\hline Z/S & 1
\end{tabular}


Figure 24: Cotton textile with selvedge to selvedge (loom width) preserved, Qasr el-Yahud, no. 13.1

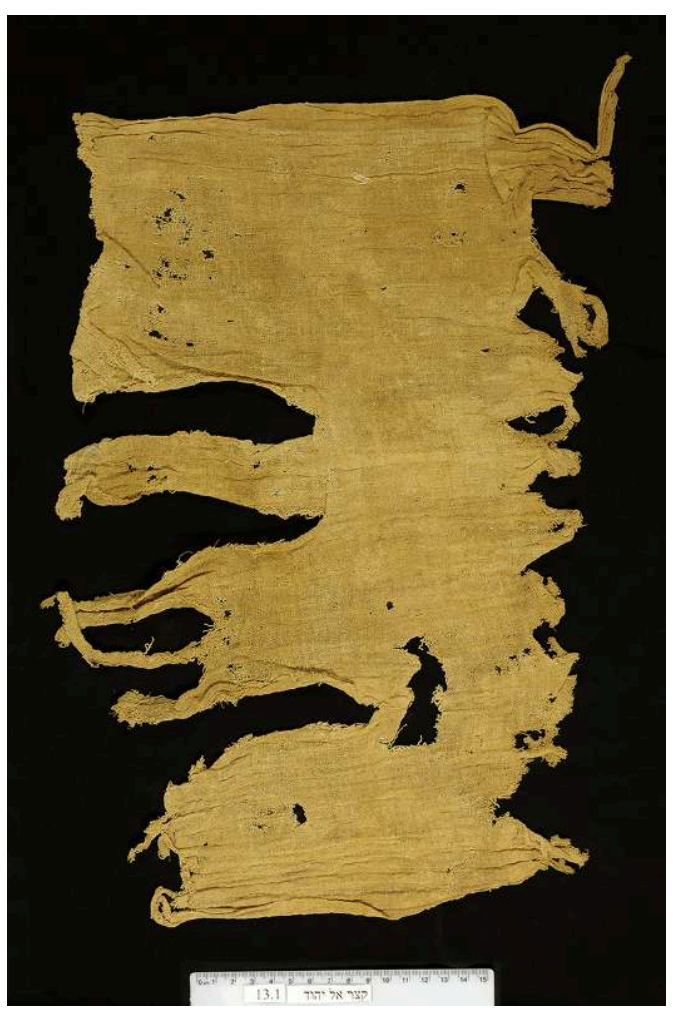

Clara Amit, Israel Antiquities Authority

47 The textiles from Qasr el-Yahud are of great importance, as they are precious witnesses of Christian burial customs during the Late Islamic period. The deceased were buried in their cloths, sometimes wrapped in a shroud and probably lying on a mat. Describing the baptism ceremony, the Piacenza Pilgrim wrote: "Some wear linen and some other materials which will serve as shrouds for burial" (Gibson 2004: 225-229). In addition, they are the only textiles dated to this period to have ever been discovered in modern Israel. Their unusual technical properties as well as the information gathered during the anthropological study seem to corroborate in proving the foreign origin of both the textiles and their owners, probably coming to Palestine from Egypt and/or Nubia9.

\section{'Avdat-the Cave of the Saints}

The items from the Cave of the Saints at 'Avdat were discovered during the excavations conducted in 1993 by O. Katz, on behalf of the Israel Antiquities Authority (Baginski \& Shamir 2001). The cave had previously been excavated by A. Negev (1993) and G. Tahal (1994). Katz excavated the entry to the hewn cave and found the textiles and cordage among the debris on the floor (pers. comm.). Samples were dated by radiocarbon to 1169-1242 $\mathrm{CE}^{10}$ (Baginski \& Shamir 2001: 260). The date coincides with textiles and cordage from other sites of this period, e.g. Jazirat Fara'un (Baginski \& Shamir 1998) and Qarantal Cave 38 (Shamir \& Baginski 2013). Other artifacts from the cave, such as ceramics, can be dated on stylistic grounds to the Late Byzantine and Early Islamic periods (Katz, pers. comm., Tahal 1994).

The corpus counts 80 textile fragments made of cotton, linen, wool, goat hair, and mixed materials. They are fragmentary, torn, cut, patched and/or reused. Twenty-eight 
items are of cotton, most of them Z-spun in both warp and weft. Three are printed: two in blue on a cream ground (Figure 25) and one in purple (faded) on a cream ground. Such printed textiles have also been discovered on contemporary Egyptian sites, e.g. Quseir al-Qadim (Vogelsang-Eastwood 1990), Fustât (Hoskins 2002, Mackie 1989), and Jazirat Fara'un (Baginski \& Shamir 1998). All are Z-spun, including those from Quseir alQadim (Vogelsang-Eastwood 1990: 15) and Fustât (Mackie 1989: 88). It can be assumed that the printed cotton fragments originated in India (Barnes 1996, Endrei 1994, Erikson 1997).

Figure 25: 'Avdat-the Cave of the Saints, printed, blue on a cream ground. IAA No. 1997-9152

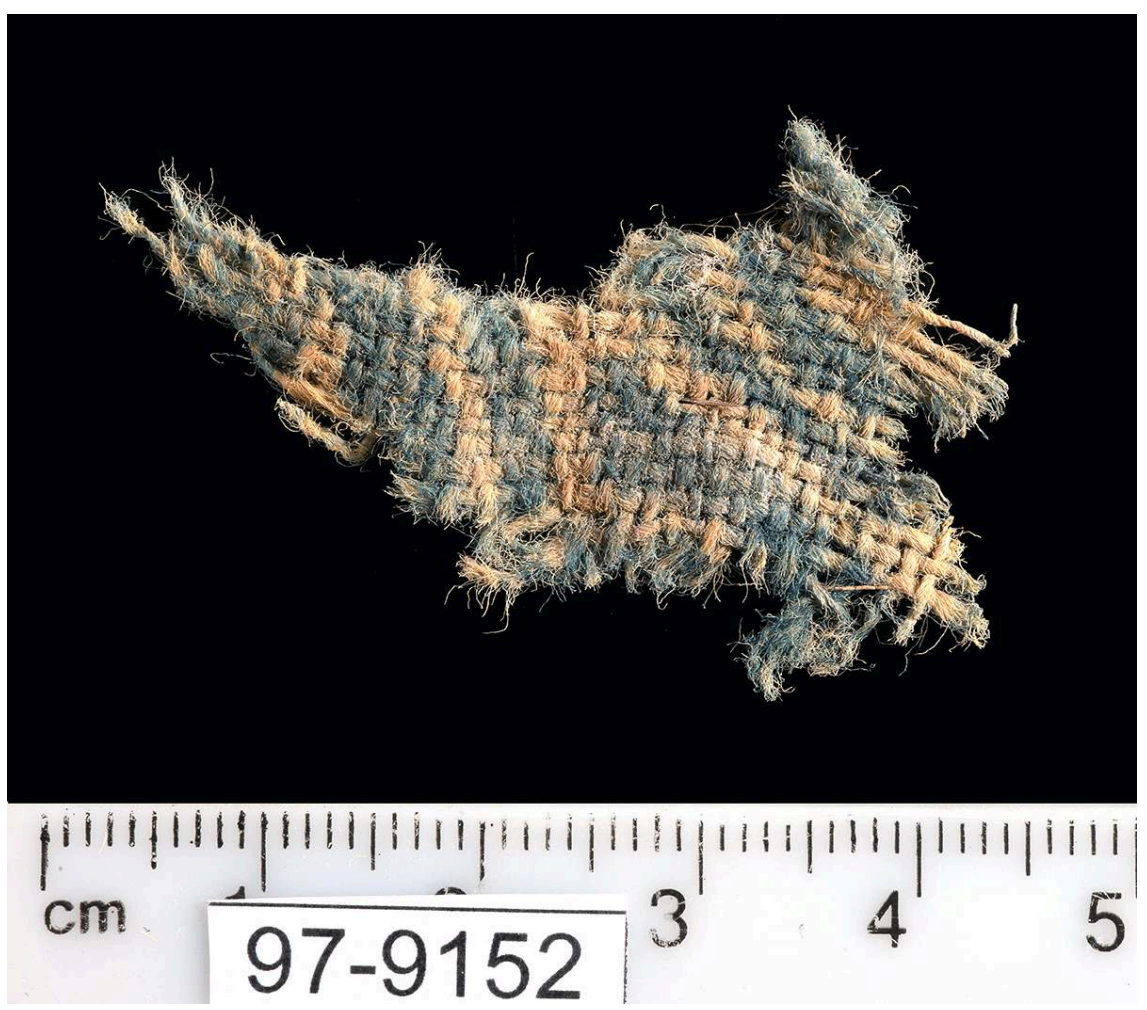

Clara Amit, Israel Antiquities Authority

\section{Qarantal Cave 38} material dated to the $9^{\text {th }}$ century to the end of the $13^{\text {th }}$ century textiles were discovered. Out of this large group, 285 pieces are made of Z-spun cotton.

Within the cotton textiles, 134 used an S-spun linen warp and a Z-spun cotton weft. They form a unique group by their sheer quantity, since only a few similar fabrics have been discovered on other sites of the same region. The presence of linen may appear odd during this period, since we know from other sources that linen production sharply declined in Palestine after the Islamic conquest. It became then significantly cheaper to import it from Egypt, which was now part of the same political unit. By the early Middle Ages, flax cultivation had ceased almost entirely in the Levant. The use of flax and its products remained nonetheless popular and widespread, thanks to imported stocks from various countries, especially from Egypt (Amar 1998: 114). It continued to be appreciated by the weavers and their customers, prompting a demand 
for mixed linen and cotton fabrics. Flax fibers are longer, stronger, and smoother than cotton ones, making linen a very good candidate to create a new and solid warp able to support on the loom the weight of the whole fabric in tension. Cotton on the other hand is softer and more elastic, ideally suited for the weft. Local weavers took advantage of the different properties of each fibre, combining them in the same weave in order to produce soft but strong fabrics.

It can be assumed that the people who stored the textiles in the cave were rag collectors or merchants who collected them for the paper-making industry. Following the Arab conquest, a new demand for vast quantities of paper appeared, prompting the development of a paper-making industry using the waste products from local cotton manufacturing (Amar 2002, Kedar 2018, Shamir \& Baginski 2018: 334). In response, cotton production underwent a profound shift which redefined the fiber's usage: primarily cultivated to produce cloths, cotton then became also the first raw material needed to prepare paper. It was made by breaking down different organic materials into a fibrous pulp, using linen, cotton, and date-palm leaves and fibers. These fibers were soaked in water and separated using a fine netted sieve. Sent from ancient Palestine to Cairo, the Geniza letters mentioned above are for example made in such a technique: the principal material is cotton (73\%), sometimes mixed with flax (14\%), wool, and other unidentified materials (Amar et al. 2010).

\section{Coral Island (Jazirat Fara'un)}

53 The medieval fortress on Coral Island (Jazirat Fara'un) is located in the Red Sea, $14 \mathrm{~km}$ south of the modern city of Eilat in modern Israel. Excavations were carried out by A. Goren from 1975 to 1981 (the final report was not published). About 1500 textile fragments, 700 basketry fragments, and 700 pieces of cordage were discovered at the site. Off this large corpus, 236 textiles were selected for further analyses. On the basis of the pottery and radiocarbon studies, the material has been dated to the $13^{\text {th }}$ century CE. The island, a solid granite rock, measures $300 \mathrm{~m}$ from north to south, and approximately $150 \mathrm{~m}$ from east to west at its widest point. It is of strategic importance, at the junction of the Red Sea route leading to Southern Arabia and East Africa, and the land routes leading to Syria and Egypt (Rothenberg 1961: 185). On the west, facing the shore of the Gulf, lies a shallow lagoon which can be entered by boat at high tide, and was used as a sheltered harbor in the $13^{\text {th }}$ century CE.

Most of the textiles were discovered in the middens, in contrast to the many basketry and cordage fragments recovered within the building structures. As there is no sign of sudden destruction, it can be assumed that the inhabitants deserted the island, taking their garments and other valuable textiles with them and abandoning only used mats, baskets, and cordage fragments. A similar situation was observed at the Early Islamic site of Nahal 'Omer, where textile scraps were found in the middens, while the basketry and cordage were discovered in the ruins of the buildings.

56 The textiles display a large variety of materials - cotton, linen, silk, wool, and mulham (see below) - and different techniques, dyes, decorations, and patterns. No complete garments were discovered, as most fragments had been cut into strips, rectangles, or triangles. Many were stained, some were faded, and several had a foreign substance such as bitumen (?) adhering to them. 

and undecorated cotton tabbies, while a few fragments display assorted checked patterns in blue and cream/white colours. This type of checked fabrics was seemingly highly fashionable during the medieval period, being also attested in the textile assemblage of Cave 38 (Shamir \& Baginski 2013) and Qasr el-Yahud (Shamir 2015: 51). It is the most common pattern observed on the Egyptian sites of Quseir al-Qadim (Vogelsang-Eastwood 1982) and Fustât (Mackie 1989: 88-89), and can also be found in Telem in West Africa (Bolland 1991).

\section{Mulham textiles}

Twenty-two textiles from Coral Island have silk warps and cotton hidden wefts, a specific weave known as mulham (Baginski \& Shamir 1998). All the mulham textiles at Coral Island are warp-faced, the weft being almost invisible (Figure 26). The silk warp has coloured stripes, while the weft is either undyed or light blue. One mulham is also decorated with a very delicate silk tapestry band of fine brown scrolls on a beige ground. Garments made of this delicate fabric could sometimes be lined: we know of a sleeve from a mulham garment which was lined with an undyed cotton fabric, in a similar way as the linen tunic of Bishop Timotheos (Crowfoot 1977: 46).

Figure 26: Mulham textile, Coral Island (Jazirat Fara'un)

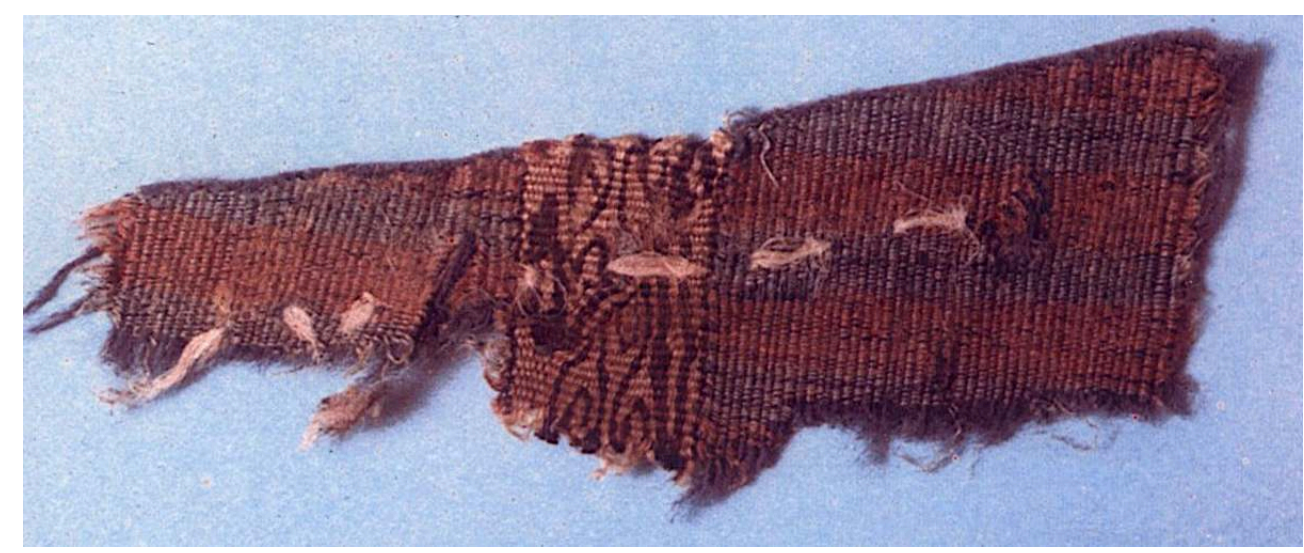

Clara Amit, Israel Antiquities Authority

The relatively large number of mulham textiles is unique to Coral Island (Baginski \& Shamir 1998). None was discovered at Quseir al-Qadim (Vogelsang-Eastwood 1982) and only 11 specimens were found at Fustât, where all their wefts are Z-spun. Most of the Fustât examples are warp faced and striped, with undyed yellowish or light blue cotton wefts. Some textiles have alternating silk and cotton wefts (Mackie 1989: 89). Near Jericho, Cave 38 yielded only one mulham textile (Shamir \& Baginski 2013). This type of textile is however more familiar in the corpus of Tiraz fabrics (Golombeck \& Gervers 1977, Ng 2001, Mackie 2015). In the $9^{\text {th }}$ century CE, the caliph al-Mutawakkil even set a trend when he wore in public a shiny half-silk textile called mulham. The technic offered an economical way to make the most of silk yarns, which was significantly more expensive than cotton or linen. Probably cheaper than pure silk textiles, mulham fabrics quickly became very popular all over the Islamic world, where they were aimed at a market of moderate wealth (Xinru 2010). They were also designed in response to Islamic law, which prohibited male clothing made of pure silk. Together with gold, silk 
was a forbidden adornment to pious men: the hadith of 'Ali ibn Abi Talib said that the Prophet took some silk in his right hand and a piece of gold in his left hand, declaring "These two are haram for the males among my followers."

Mulham textiles were not produced in Egypt but started to be mentioned in literary sources of the $9^{\text {th }}$ century in Iraq and Iran, where they seem to originate and then spread through the Islamic world (Mackie 1989, Shepherd 1953, Lamm 1937: 5).

\section{Block-printed textile}

Beside checked and mulham fabrics, four other textiles display block-printed décor on undyed cotton (Figures 27-28). Three of them are resist-dyed blue on an undyed ground, with for example a pattern repeat of small rosettes placed in the center of a diamond-shaped grid and wide monochrome dark blue borders. Another one has red floral motifs of four-petaled rosettes, stems, and leaves on a beige ground. Due to the fragmentary condition of the textile, the pattern was unidentifiable. All known examples are made with Z-spun cotton threads.

Figure 27: Pattern repeat of small rosettes in the center of a lozenge grid and wide monochrome dark blue border, Coral Island (Jazirat Fara'un)

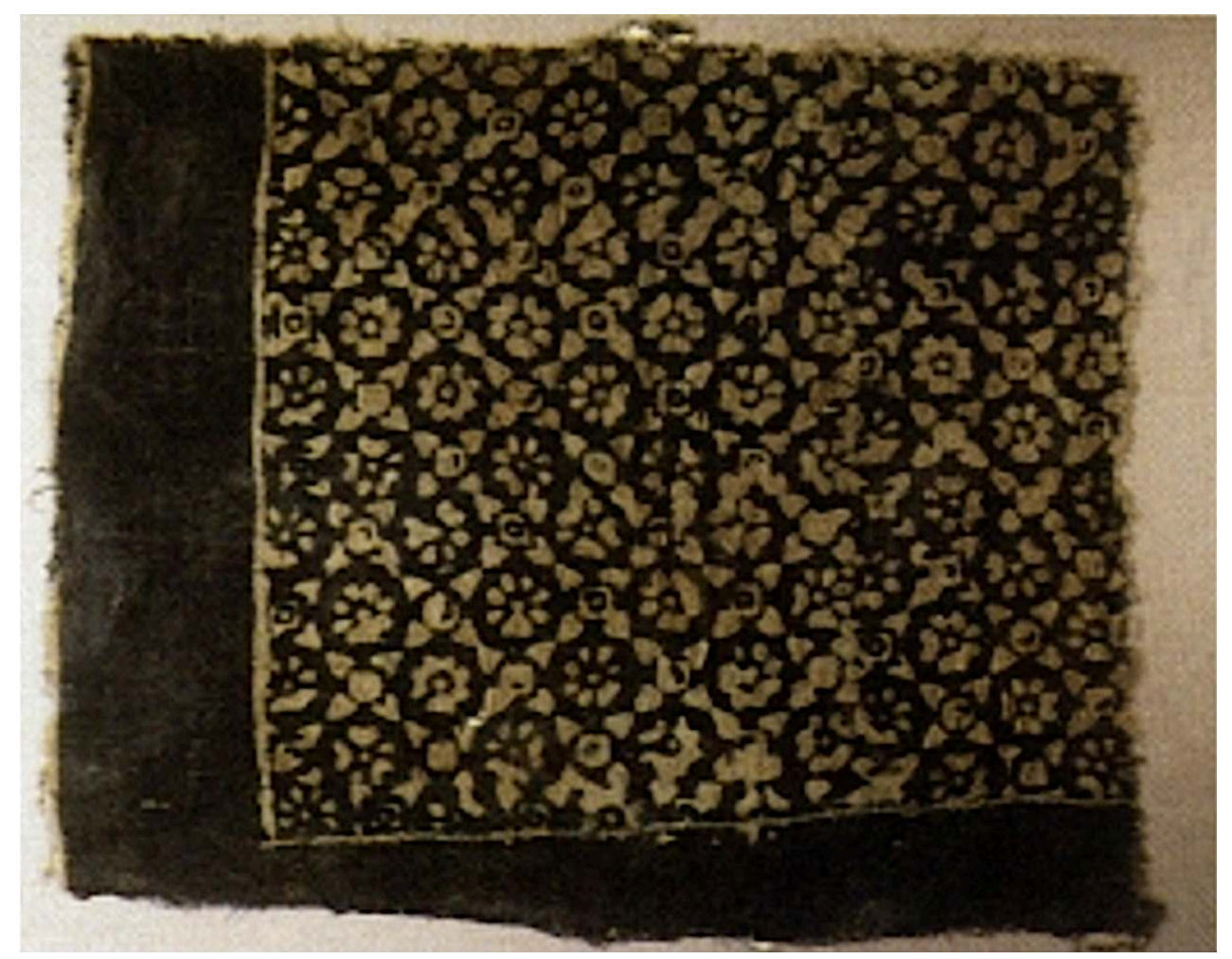

Clara Amit, Israel Antiquities Authority 
Figure 28: Red floral motifs on a beige ground which were probably mordant printed, Coral Island (Jazirat Fara'un)

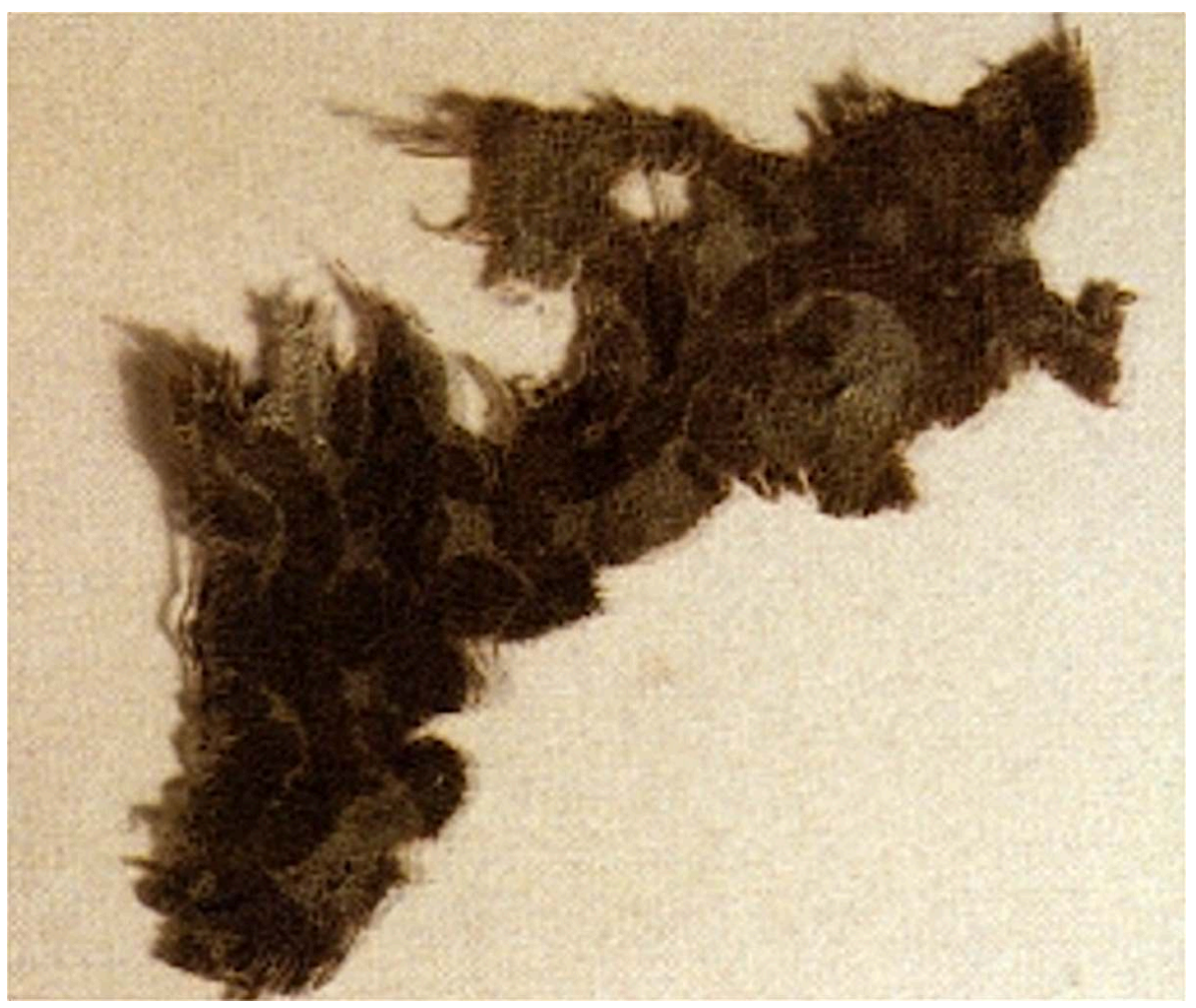

Clara Amit, Israel Antiquities Authority on the fabric, such as the reds extracted from madder roots. First the mordant was printed on the fabric, which was then immersed in the color bath, and finally washed in hot water. The mordant reserved their color, while it was washed out from the untreated areas where the fabric retained its original shade.

Because of the distinctive $\mathrm{Z}$ spun direction and techniques, block-printed fabrics are thought to originate in India. After the Periplus of the Erythraean Sea, a Greco-Roman guide to trade and navigation between India and the Roman Empire during the $1^{\text {st }}$ century CE, scholars have identified the Indus valley and the great port of Barbarikon in the Indus Delta as a centre of cloth production and export (Periplus 39, Casson 1989 $)^{12}$. Despite its mention in the Periplus, resist-dyeing was still an expensive technique in the ancient world (Wild \& Wild 2014b: 94) and examples of Z/Z resist-dyed cottons remained rare in Roman Egypt. They were found in the Egyptian Eastern desert port of Berenice, $1000 \mathrm{~km}$ south of Suez. Probably used as wall hangings and curtains, they date to the late $4^{\text {th }}$ or $5^{\text {th }}$ century CE. The decorative repertoire is dominated by stylised plant motifs. They were drawn or painted by the artist-dyers on fine undyed cotton cloth using a liquid resist medium such as hot wax. Z/Z resist-dyed cotton textiles were found on other Egyptian sites, such as Abu Sha'ar ( $5^{\text {th }}$ century CE), Akoris (Wild \& Wild 1996: 252, 256), Kellis in the Dakhlah Oasis, and Kalabsha in southern Egypt (Wild \& Wild 2014a: 223-225) ${ }^{13}$. We also know of other examples from Palmyra in Syria and Al-Tar in Iraq. All dated to the $4^{\text {th }}$ and $5^{\text {th }} \mathrm{C}$. CE, these indigo resist-dyed cotton fragments are all Indian productions (Power 2010: 64, Wild \& Wild 2000: 
271-273). They prove the continuation of this maritime textile trade during Late Antiquity and are witnesses to the burgeoning Muslim trade in Indian textiles.

Their exportation to the Middle East developed during the medieval period, during which they appear at Coral Island, Quseir al-Qadim, and Fustât. They are also mentioned in the Geniza documents, found in Cairo but originating from Palestine and dated to the $10^{\text {th }}-11^{\text {th }} \mathrm{C}$. CE, which related the import of cotton textiles from India to Egypt (Vogelsang-Eastwood 1990: 6). From these sources, it appears that the Indian block-printed cotton textiles were designed for a "middle-class" and "intended for a popular rather than luxury market" (op.cit.: 7). In a medieval textile world rich of resistdyeing techniques, block-printing must have been commoner and therefore less expensive than other, more time-consuming, techniques such as ikats (John-Peter Wild, pers. comm.). However, created as unique pieces by skilled craftsmen, block-printed fabrics were by no mean a cheap item either: targeting the affluent "middle classes" of the Islamic world, they were valuable enough to justify their import from far-away India. The importance of the printed textiles lies in the fact that they represent a major trade item which we can track throughout the eastern Mediterranean world, the Near East, India, and the Far East (Vogelsang-Eastwood 1990: 8, Desrosiers et al. 2001).

\section{Wadi Murabba'at}

Wadi Murabba'at is located $18 \mathrm{~km}$ south of Qumran in the Judean Desert. Some of the artefacts found at the site are dated to the $11^{\text {th }}-13^{\text {th }} \mathrm{c}$. CE, among which we note 22 textiles out of 28 made of cotton. One of them is blue with cream stripes. Five textiles are made from mixed cotton and linen, usually with a linen warp and a cotton weft. We also observe one twill textile made of mixed cotton and wool (Figure 29) (Crowfoot \& Crowfoot 1961: 61-62; pers. obs.).

Figure 29: Blue cotton textile with cream stripes, Wadi Murabba'at, IAA No. 492165

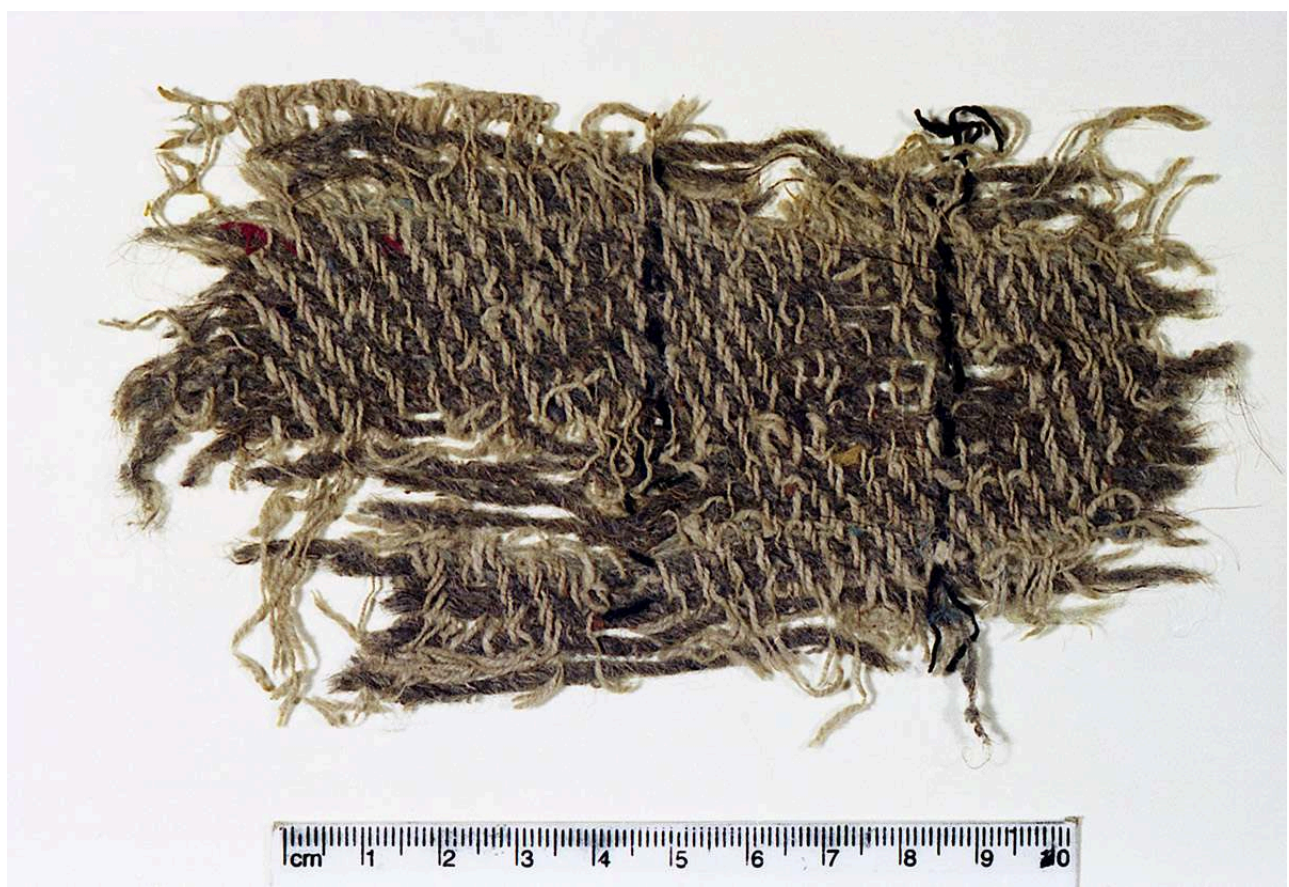

Clara Amit, Israel Antiquities Authority 


\section{Mezad Zohar}

In 2004, 20 textile fragments were discovered during the excavation of Mezad Zohar fort, located $2 \mathrm{~km}$ west of the Dead Sea (Erickson-Gini et al. 2016). Six textile fragments were found below the collapse of the upper level (Area B, L401), while seven accompanied two adult skeletons unearthed in the lower level of the fort (Area B, L1201, L1202). Two were found in the man-made cave dug alongside the road. Radiocarbon analyses confirmed the textiles' date to the $13^{\text {th }}$ century CE (RTD 8307). Within this corpus, four are made of cotton. The threads are Z-spun, forming a plain, usually balanced, weave. The one shown in figure 30 was decorated with grids of blue and white. The fragment shown in figure 31 is made of a linen warp and a cotton weft, both Z-spun (Shamir \& Sukenik 2016).

Figure 30: Cotton textile decorated with grids of blue and white, Mezad Zohar, IAA No. 2014-9004

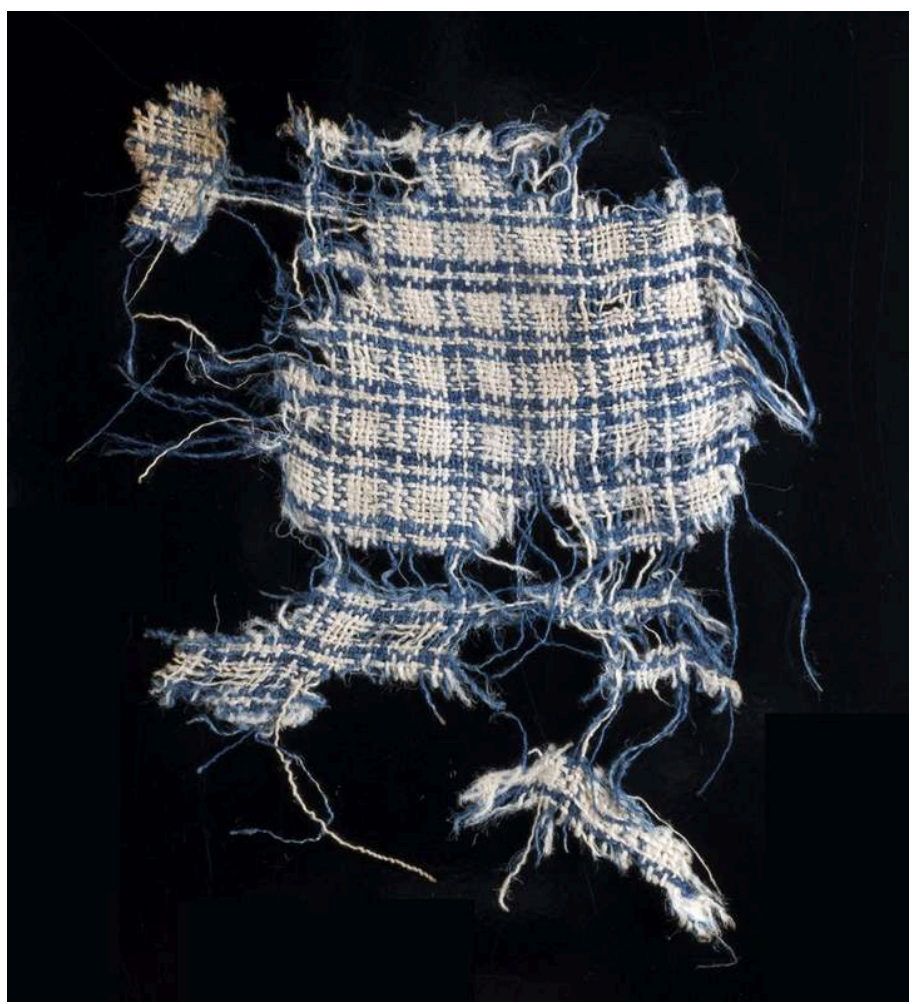

Clara Amit, Israel Antiquities Authority 
Figure 31: Linen warp and cotton weft textile, Mezad Zohar, IAA No. 2014-9006

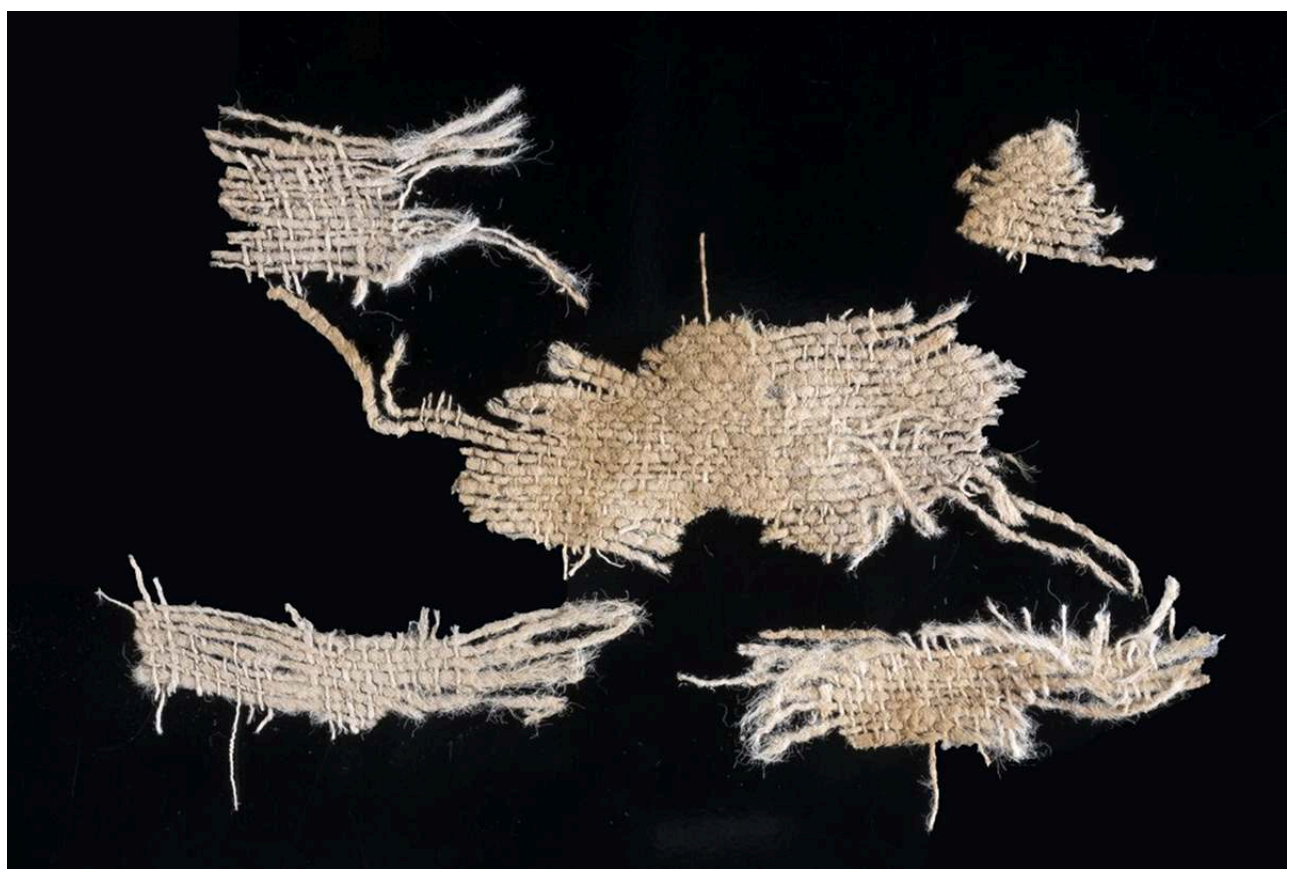

Clara Amit, Israel Antiquities Authority

\section{Summary}

67 Through the duration of the Byzantine period, in the $5^{\text {th }}-6^{\text {th }} C$. CE, cotton remained rather rare in Palestine. It continued to be infrequent during the Islamic period, leading to very few discoveries on selected sites. At least one of these location shows that cotton was also a foreign product coming mainly through importation networks with India. Such commerce has left a strong imprint on the textile landscape of ancient Palestine. The caravan town of Nahal 'Omer has left us a rich textile assemblage of good quality pieces where cotton was predominant, attesting the prosperity of the site's inhabitants and the travellers who frequented it. These finds contrast sharply with the textiles characterizing nearby sites of the same period. In most of Palestine except for Nahal 'Omer, wool was still the fibre of choice during the Early Islamic Period $\left(7^{\text {th }}-8^{\text {th }} c\right.$. CE) in sites such as Nahal Shahaq, 'En Evrona, 'En Marzev (Yahav), and Yotvata.

The exceptional quantities of silk and cotton fabrics discovered at Nahal 'Omer testifies to textile encounters with faraway lands. This distinct foreign character of cotton textiles continued to be relevant during the Later Islamic period, at Qasr el-Yahud for example, where cotton textiles are associated to Nubians and South Egyptians pilgrims. Nonetheless, local cotton production continued to be slowly developed through the medieval period, until the fibre became quite prevalent and even replaced linen. 


\section{BIBLIOGRAPHY}

Al-Muqadassi A.M. 1906 - Ahsan al-Taqasim fi Ma'rifat al-Aqalim. In : De Goeje M.J. (Ed.), Kitab Ahsan at-Taqasim fi Ma'refat al-Aqalim. Beirut, Dar Sader.

Amar Z. 1998 - Written Sources Regarding the Jaziret Fara'un (Coral Island) Textiles. 'Atiqot 36 : 114-119.

Amar Z. 2002 - The History of the Paper Industry in Al-Sham in the Middle Ages. In : Lev Y. (Ed.), Towns and Material Culture in the Medieval Age in Middle East. Leiden, Brill : 135-58.

Amar Z., Gorski A. \& Neumman N. 2010 - The Paper and Textile Industry in Light of an Analysis of the Cairo Genizah Documents. In : Outhwaite B. \& Bhayro S. (Ed.), From a Sacred Source, Genizah Studies in Honour of Professor Stefan C. Reif. Leiden, Boston, Brill : 25-42. (Études sur le Judaïsme médiéval ; 42).

Amar Z. \& Serri Y. 2004 - The Land of Israel and Syria as described by Al-Tamimi, Jerusalem, Bar-Ilan University press, $174 \mathrm{p}$.

Amar Z. \& Shamir O. 2013 - Egyptian Balsam and its Uses. Judea and Samaria Research Studies 25 : 369-376 (in Hebrew).

Baginski A. \& Shamir O. 1995 - Early Islamic Textiles, Basketry and Cordage from Nahal Omer. 'Atiqot $26: 21-42$.

Baginski A \& Shamir O. 1998 - Textiles, Basketry and Cordage from Jeziret Fara'un (Coral Island). 'Atiqot $36: 39-122$.

Baginski A. \& Shamir O. 2001 - Textiles and Cordage from 'Avdat - the Saints Cave. 'Atiqot 42 : 243-260.

Barnes R. 1996 - Indian Trade Textiles. Hali 87 : 80-85.

Bellinger L. 1962 - Textiles. In : Colt H.D. (Ed.), Excavations at Nessana 1. London, British School of Archaeology in Jerusalem : 91-105.

Ben-Michael J., Israel Y. \& Nahlieli D. 2018 - Nahal 'Omer: a Village from the early Islamic Period in the 'Arava. Excavations and Surveys in Israel 129. [Accessed 31/03/2019 at http://www.hadashotesi.org.il/images//Nahal\%200mer.]

Bolland R. 1991 - Tellem Textiles. Archaeological Finds from Burial in Mali's Bandiagara Cliff. Amsterdam, Tropenmuseum/Royal Tropical Institute, 320 p. (Mededelingen van het Rijksmuseum voor volkenkunde, Leiden ; 27).

Bühler A. 1972 - Ikat Batik Plangi. Reservemusterungen auf Garn und Stoff aus Vorderaisien, Zentralasien, Südosteuropa une Nordafrika. Basel, Pharos-Verlag, 3 v.

Cardon D. 1998 - Textiles archéologiques de Maximianon-Al Zarqa et Didymoi : exemples précoces de teinture par réserve sur laine. Bulletin de Liaison du Centre International d'Étude des Textiles Anciens 75 : 15-20.

Carmi I. 1987 - Rehovot Radiocarbon Measurements III. Radiocarbon 29 : 100-114.

Carmi I. \& Segal D. 1995 - Radiocarbon Dating of Early Islamic Textiles in the 'Arava Valley. 'Atiqot $26: 55-56$.

Carmi I. \& Segal D. 2004 - Rehovot Radiocarbon Date List VI. 'Atiqot 48 : 123-148. 
Casson L. 1989 - The Periplus Maris Erythraei. Text with Introduction, Translation and Commentary. Princeton University Press, 344 p.

Casson L. 1998 - Everyday Life in Ancient Rome. Baltimore-London, The John Hopkins University Press, $184 \mathrm{p}$.

Ciszuk M. 2004 - Taqueté and damask from Mons Claudianus: A discussion of Roman looms for patterned textiles. In : Alfaro C., Wild J.P. \& Costa B. (Ed.), Purpureae Vestes: Actas del I Symposium Internacional sobre Textiles y Tintes del Mediterráneo en época romana. Valencia, Publicacions de la Universitat de València : 107-113.

Cohen R. 1991 - Ancient Routes from Petra to Gaza in Light of New Findings. In : Orion A. \& Eni Y. (Ed.), The Spice Route. Sedé Boker : 28-77 (in Hebrew).

Colt H.D. 1962 - Excavations at Nessana 1. London, British School of Archaeology in Jerusalem.

Crowfoot E.G. 1977 - The Clothing of a Fourteenth Century Nubian Bishop. Studies in Textile History :43-51.

Crowfoot G.M. \& Crowfoot E. 1961 - The Textile and Basketry. In : Benoit P. et al., Discoveries in the Judaean Desert II: Les Grottes de Murabba'at. Oxford, Clarendon Press : 51-63.

Dauphin C. 1996 - Leprosy, lust and lice: Health and hygiene in Byzantine Palestine. Bulletin of the Anglo-Israel Archaeological Society 15 : 75-80.

Desrosiers S., Debaine-Francfort C. \& Idriss A. 2001 - Two Resist-Dyed Cottons Recently Found at Karadong, Xinjiang (Third Century ad)'. In : Rogers P.W., Jørgensen L.B. \& Rast-Eicher A. (Ed.), The Roman Textile Industry and its Influence: A Birthday Tribute to John Peter Wild. Oxford, Oxbow Books : 48-55.

Emery I. 1966 - The Primary Structures of Fabrics. Washington D.C., Textile Museum, 339 p.

Endrei W. 1994 - Printed Textiles from the Abemayar Collection in the Royal Ontario Museum, Toronto. Bulletin du Centre International d'Etude des Textiles Anciens $72:$ 35-47.

Erikson M. 1997 - Textiles in Egypt 200-1500 AD : in Swedish Museum Collections. Gothenburg, The Rohsska Museum : 218-221.

Erickson-Gini T., Nahlieli D. \& Kool R. 2016 - Mezad Zohar: A Medieval Fort Near the Dead Sea. Bulletin of the Anglo-Israel Archaeological Society $34: 125-150$.

Frei K.M. 2015 - The Traceable Origin of Textiles. In : Nosch M.L., Zhao F., Varadarajan L. (Ed.). Global Textile Encounters. Oxford, Oxbow Books : 87-92. (Ancient Textiles Series ; 20).

Frei R., Mannering U., Gleba M., Nosch M. L. \& Lyngstrøm H.S. 2009 - Provenance of ancient textiles: a pilot study evaluating the Sr. Isotope system in wool. Archaeometry $51: 252-276$.

Gal Z. 2011 - Baptism in the Jordan River. Israel Nature and Parks Authority.

Gibson S. 2004 - The Cave of John the Baptist: The Stunning Archaeological Discovery that has Redefined Christian History. London, $400 \mathrm{p}$.

Gichon M. 1993 - 'En Boqeq. In : Stern E. \& Gilboa A. (Ed.). New Encyclopedia of Archaeological Excavations in the Holy Land II. Jerusalem, Israel Exploration Society \& Carta : 395-399.

Gichon M. 2000 - En Boqeq. Ausgrabungen in einer Oase Am Toten Meer I. Mainz Am Rhein, Zabern, $361 \mathrm{p}$.

Golombeck L. \& Gervers V. 1977 - Tiraz Fabrics in the Royal Ontario Museum. In : Gervers V. (Ed.), Studies in Textile History, in Memory of Harold B. Burnham. Toronto, Royal Ontario Museum : 82-125. 
Granger-Taylor H. 2000 - The Textiles from Khirbet Qazone (Jordan). In : Cardon D. \& Feugere M. (Ed.). Archéologie des textiles des origines au ve siècle. Actes du colloque de Lattes, octobre 1999.

Montagnac, Éditions Mergoil : 149-162. (Monographie Instrumentum ; 4).

Herschberg A.S. 1924 - Textiles and the Textile Industry. Warsaw, Shtibl. (in Hebrew).

Hoskins N.A. 2002 - Textiles. In : Bacharach J.L. (Ed.), Fustat Finds: Beads, Coins, Medical Instruments, Textiles, and Other Artifacts from the Awad Collection. Cairo, AUC Press : 225-268.

Kedar B.Z. 2018 - The Use of Paper in the Frankish Levant: A Comparative Study. In : Menache S., Kedar B.Z. \& Balard M. (Ed.). Crusading and Trading between West and East: Studies in Honour of David Jacoby: 3-16.

Korenfeld I. 2015 - Ramla. Final report. Hadashot Arkheologiyot, Excavations and Surveys in Israel 127. [http://www.hadashot-esi.org.il/report_detail_eng.aspx?id=18758\&mag_id=122]

Lamm C.J. 1937 - Cotton in Mediaeval Textiles of the Near East. Paris, Librairie orientaliste.

Mackie L.W. 1989 Textiles. In : Kubiak W. \& Scanlon G.T. (Ed.), Fustat Expedition

Final Report: Fustat-C, vol. 2. Cairo, ARCE : 81-101.

Mackie L.W. 2015 - Symbols of Power: Luxury Textiles from Islamic Lands, 7th-21st Century. Cleveland, The Cleveland Museum of Art.

Millas Vallicrosa J. \& Aziman M. (Ed.) 1955 - Ibn Bassál: Libro de agricultura. Tetuán: Instituto Muley El-Hasan.

Ng D. 2001 - Journey to the West: The Kelsey Mulham in the Context of the Political Usage of Tiraz by the Abbasids and the Tulunids. The University of Michigan Museum of Art and Archaeology Bulletin $14: 63-78$

Patrich J. 1984 - Judean Desert. Secret Passages and Caves. Excavations and Surveys in Israel 3 : 61-62.

Patrich J. 1994 - Khirbet Qumran in the Light of New Archaeological Explorations in the Qumran Caves. In : Wise M.O., Golb N., Collins J.J. \& Pardee D.G. (Ed.), Methods of Investigation of the Dead Sea Scrolls and the Khirbet Qumran Site: Present Realities and Future Prospects, Annals of the New York Academy of Sciences 722. New York, New York Academy of Sciences : 73-95.

Patrich J., Arubas B. \& Agur B. 1988-1989 - Judean Desert, Cave Survey - 1986/1987. Excavations and Surveys in Israel 7-8: 92-95.

Politis K.D. 1998 - Rescue Excavations in the Nabatean Cemetery at Khirbet Qazone 1996-1997. Annual of the Department of Antiquities of Jordan 42 : 611-614.

Politis K.D. 1999 - The Nabatean Cemetery at Khirbet Qazone. Near Eastern Archaeology 62 : 128. Porath Y. 2016 - Tunnel-Well (Qanat) Systems and Settlements from the Early Islamic Period in the 'Arava. 'Atiqot $86: 113-116$.

Power T. 2010 - The Red Sea Region During the 'Long' Late Antiquity (AD 500-1000). D.Phil. Dissertation Faculty of Oriental Studies University of Oxford.

Rahmani L.Y. 1967 - Jason's Tomb. Israel Exploration Journal 17 : 61-100.

Riello G. 2014. The World of Textiles in Three Spheres: European Woolens, Indian Cottons and Chinese Silks (1300-1700). In : Nosch M.L., Zhao F. \& Varadarajan L. (Ed.), Global Textile Encounters : 93-106. (Ancient Textiles Series ; 20).

Rothenberg B. 1961 - God's Wilderness. Discoveries in Sinai. London, Thames \& Hudson. 
Safrai Z. 1994 - The Economy of Roman Palestine. London, Routledge.

Schick T. 1988 - Nahal Hemar Cave- Cordage, Basketry and Fabrics.'Atiqot (ES) 18 : 31-42.

Seland E.H. 2014 - Early Christianity in East Africa and Red Sea/Indian Ocean Commerce. African Archaeological Review 31 : 637-647

Shamir 0. 1995 - Textiles from Nahal Shahaq, Israel. 'Atiqot 26 : 43-48.

Shamir O. 1999 - Linen Textile from Tomb 3. In : Varga D., Be'er Sheva - Civic Center. Excavations and Surveys in Israel 19 : 90-91.

Shamir 0. 2007a - Textiles in the Land of Israel from the Roman Period till the Early Islamic Period in the Light of the Archaeological Finds, PhD dissertation, Jerusalem.

Shamir O. 2007b - Textiles, Cordage, and Threads from En-Gedi. In : Hirschfeld Y. (Ed.), En-Gedi Excavations II, Final Report (1996-2002). Jerusalem, Israel Exploration Society, Institute of Archaeology : 587-594.

Shamir 0. 2007c - Textiles. In : Kogan-Zehavi E. (Ed.), Remains of Early Islamic Settlement and a Hellenistic (Roman?) Tomb at Khirbat Deiran, Rehovot. 'Atiqot 57 : 86-87.

Shamir 0. 2015 - Egyptian and Nubian textiles from Qasr el-Yahud, 9th century AD. In : De Moor A., Fluck C. \& Linscheid P. (Ed.), Textiles, tools and techniques of the 1st millennium AD from Egypt and neighbouring countries, Proceedings of the 8th conference of the research group "Textiles from the Nile Valley" (4-6 October 2013, Antwerp). Lannoo, Tielt : 48-60.

Shamir O. 2016a - Textiles and Fleece from 'En Marzev, the Early Islamic period. 'Atiqot 86 : 11-19. Shamir 0. 2016b - Textiles, Cordage and Fleece from 'En 'Evrona, the Early Islamic period. 'Atiqot $86: 3-9$.

Shamir 0. 2016c - Textile Trade to Palestine in the Roman Period according to the Talmudic Sources and the Textiles finds. In : Droß-Krüpe K. \& Nosch M.L. (Ed.), Textiles, Trade and Theories: From the Ancient Near East to the Mediterranean. Münster, Münster Ugarit : 231-246.

Shamir O. 2017a - The High Priest Sha'atnez Garments Compared to Textiles Found in the Land of Israel. In : Brøns C. \& Nosch M.L. (Ed.), Textiles and Cult in the Ancient Mediterranean. Oxford, Oxbow Books : 199-208. (Ancient Textiles Series ; 31).

Shamir 0. 2017b - Sha'atnez - The Biblical Prohibition against Wearing Mixed Wool and Linen Together and the Observance and Enforcement of the Command in the Orthodox Jewish Communities Today. In : Gaspa S., Michel C. \& Nosch M.L. (Ed). Textile Terminologies from the Orient to the Mediterranean and Europe 1000 BC-AD 1000. Lincoln, University of Nebraska, Zea EBooks : 164-172. [http://digitalcommons.unl.edu/zeabook/56]

Shamir O. \& Baginski A. 2002 - The Later Textiles, Basketry and Cordage from Caves in the Northern Judean Desert ("Operation Scroll"). 'Atiqot 41 : 241-256.

Shamir O. \& Baginski A. 2013 - 'Textiles' Treasure from Jericho Cave 38 in the Qarantal Cliff Compared to other Early Medieval Sites in Israel. In : Textiles and Politics, Textile Society of America Symposium Proceedings. Lincoln, University of Nebraska : 742. [http://digitalcommons.unl.edu/ cgi/viewcontent.cgi?article=1741\&context=tsaconf]

Shamir O. \& Baginski A. 2014 - The Earliest Cotton Ikat Textiles from Nahal 'Omer Israel 650-810 CE. In : Nosch M.L., Feng Z. \& Varadarajan L. (Ed.), Global Textile Encounters. Ancient Textiles Series 20. Oxford, Oxbow books : 65-73. 
Shamir O. \& Baginski A. 2018 - Medieval silk textiles from excavations in the Land of Israel. In : Menache S., Kedar B.Z. \& Balard M. (Ed.), Crusading and Trading between West and East: Studies in Honour of David Jacoby. London, Routledge: 227-235.

Shamir O. \& Schick T., forthcoming - Chalcolithic to Medieval Textiles from the Judean Desert Caves Survey. In : Peleg-Barkat O., Ashkenazi J., Livner U., Aviam M. \& Talgam R. (Ed.), Between Sea and Desert: On Kings, Nomads, Cities and Monks. Essays in Honor of Joseph Patrich. Tzemach: Kinneret Academic College and Ostracon.

Shamir O. \& Sukenik N. 2016 - Thirteenth Century CE Textiles from Mezad Zohar. Strata: Bulletin of the Anglo-Israel Archaeological Society 34 : 155-164.

Shanks H. 1999 - Who lies Here? Jordan Tombs Match Those at Qumran. Biblical Archaeology Review 25 : 49-53.

Sheffer A. \& Tidhar A. 1991 - The Textiles from the 'En-Boqeq Excavation in Israel. Textile History $22: 3-46$.

Shepherd D.G. 1953 - Two Islamic Embroideries in Gold on 'Mulham'. The Bulletin of the Cleveland Museum of Art 40 (188) : 190-191.

Sivaramamurti M.C. 1977 - The Art of India. New York, Harry N. Abrams.

Sukenik N., Shamir O, Rottoli M. \& Belis M. forthcoming - Textiles and Cords from Qumran Cave 11. In : Fidanzio M. (Ed.), Proceedings of the facoltà di teologia international workshop Qumran cave $11 Q$ archaeology and manuscripts (Lugano).

Tahal G. 1994 - 'Avedat. Excavations and Surveys in Israel $14: 130-133$.

Taylor J.E., Rasmussen K.L., Doudna G., Van der Plicht J. \& Egsgaard H. 2005 - Qumran Textiles in the Palestine Exploration Fund, London: Radiocarbon Dating Results. Palestine Exploration Quarter $137 / 2: 159-167$.

Watson A.M. 1983 - Agricultural Innovation in the Early Islamic World. Cambridge.

Weiner A.B. \& Schneider B. 1989 - Cloth and the Human Experience. Washington D.C., Smithsonian Institution Press.

Wild J.P. 1997 - Cotton in Roman Egypt: Some Problems of Origin. Al-Rafidan 28 : 287-298.

Wild J.P. \& Wild F.C. 1996 - The Textiles. In : Sidebotham S.E. \& Wendrich W.Z. (Ed.), Berenike 1995. Preliminary Report of the Excavations at Berenike and the Survey of the Eastern Desert. Leiden, Research School, CNWS : 246-256.

Wild J.P. \& Wild F.C. 2000 - The Textiles. In : S. E. Sidebotham and W. Z. Wendrich (eds.), Berenike 1998. Report of the 1998 Excavations at Berenike and the Survey of the Eastern Desert including Excavations at Wadi Kalalat. Leiden, Research School CNWS : 251-274.

Wild J.P. \& Wild F.C. 2014a - Through Roman Eyes: Cotton Textiles from Early Historic India. In : Bergerbrant S. \& Fossøy S.H. (Ed.), A Stitch in Time: Essays in Honour of Lise Bender Jørgensen. Gothenburg, Gothenburg University : 209-236.

Wild J.P. \& Wild F.C. 2014 b - Berenike and Textile Trade on the Indian Ocean. In : Droß-Krüpe K. (Ed.) Textile Trade and Distribution in Antiquity. Wiesbaden, Harrassowitz Verlag : 91-110.

Vogelsang-Eastwood G. 1982 - Preliminary Report on the Textiles. In : Whitcomb D.S. \& Johnson J.H. (Ed.). Quseir Al-Qadim 1980 Preliminary Report. Princeton, Udena Publications : 285-326.

Vogelsang-Eastwood G. 1990 - Resist-Dyed Textiles from Quseir al-Qadim, Egypt. Paris, AEDTA. 
Xinru L. 2010 - The Silk Road in World History. Oxford, Oxford University Press.

Yvanez E. 2016a - Textiles and Funerary Rituals. The Wrapping of Offerings at Meroe and elHobagi. Sudan and Nubia $20: 75-81$.

Yvanez E. 2016b - Spinning in Meroitic Sudan: Textile Production Implements from Abu Geili. Dotawo: A Journal of Nubian Studies $3: 153-177$.

Zhao F. \& Wada Y.I. 2014 - Introduction. In : Luximon A. (Ed.). Resist Dye on the Silkroad: Shibori, Clamp Resist and Ikat. Proceeding of the 9th International Shibori Symposium in Hangzhou, China.

Zias J. 2002 - New evidence for the history of leprosy in the Ancient Near East: An overview. In : Roberts C.A., Lewis M.E. \& Manchester K. (Ed.), The past and present of Leprosy-Archaeological, historical, palaeopathological and clinical approaches. Proceedings of the international congress on the evolution and palaeoepidemiology of the infectious diseases $3: 259-268$. (BAR International Series ; 1054).

\section{NOTES}

1. Prof. Wu Xiaohong, Archaeometry \& Archaeological Dating Laboratory Peking University Beijing. BA170529 unpublished.

2. Catalogue $\mathrm{n}^{\circ} 29,115,116$ re-examined by N. Sukenik.

3. RT 2543 conducted by Prof. Israel Carmi and Dror Segal, on behalf of the Weizmann Institute of Science, Rehovot (Shamir 2016a: 18).

4. For ease of description, the following observations will use the textile numbers attributed to each piece in the original report and inventory.

5. A tight weave has been classed by I. Emery (1966:11-12) as being above an angle of $45^{\circ}$, medium as between $45^{\circ}$ and $20^{\circ}$, while loose is classed as $20^{\circ}$ or less.

6. http://www.turkotek.com/misc_00031/conversation.htm. Accessed 14/07/2018

7. "As you can see work is done standing up and you need the upper body strength of a man to move the heavy beams and the pulling of levers" (P. Tanavoli, in http://www.turkotek.com/ misc_00031/conversation.htm. Accessed 14/07/2018

8. The "binding of Isaac" (in Hebrew Akedát Yitzák), also known as "the Binding", Akedah or Aqedah), is a story from the Hebrew Bible in which God asks Abraham to sacrifice his son, Isaac, on Mount Moriah. The account states that Abraham "bound Isaac, his son" before placing him on the altar.

9. A comparative study between contemporary cotton textiles from Qasr el-Yahud, Egypt, and Nubia could help sustaining or deny this hypothesis in the future.

10. RT-2731, Weizmann Institute of Science.

11. Reported by Ahmad, Abu Dawud, an-Nasa'i, Ibn Hayyan, and Ibn Majah, who reports the additional phrase, "but halal for the females." (https://islamqa.info/en/2037).

12. For more information about the textile trade with India, see Vogelsang-Eastwood 1990, Seland 2014, and Wild \& Wild 2014b.

13. Other examples of resist-dyes textiles have been found in Egypt, such at El-Zarqa and Didymoi (Cardon 1998), but were made on woolen fabrics. 


\section{ABSTRACTS}

In ancient Palestine, the early presence of cotton textiles can only be attested by one net dated to the Roman period. Cotton was first imported in small quantities during the Byzantine period, in the $5^{\text {th }}-7^{\text {th }}$ C. CE. During the Early Islamic Period, in the $7^{\text {th }}$ century CE, wool was still dominant in Palestine, while important groups of cotton textiles were notably found at Nahal 'Omer. They were mostly made of Z-spun threads and included precious ikats. Cotton textiles such as garments and shrouds (mostly S-spun) were discovered at Qasr el-Yahud, on the west bank of the Jordan River, dated to the $8^{\text {th }} 9^{\text {th }}$ C. CE. Cotton fragments, including resist-dyed textiles, have also been discovered at Cave 38 in the Qarantal cliff above Jericho, and date from the $9^{\text {th }}$ century CE to the end of the $13^{\text {th }}$ century CE. This article will provide the reader with a broad overview of cotton textile finds from the region, focusing on key sites but also listing the other discoveries. It will discuss the possible origin of the cotton textiles, and the co-development of the textile trade and local production, through the Late Antique and medieval periods.

En ancienne Palestine, la première trace de tissu en coton remonte à la période romaine pour laquelle nous connaissons l'existence d'un filet fabriqué avec des fils de coton. Cette fibre fut pour la première fois importée en petites quantités pendant la période byzantine $\left(\mathrm{V}^{\mathrm{e}}-\mathrm{VII}{ }^{\mathrm{e}}\right.$ siècle $\mathrm{EC})$. Au début de la période islamique, pendant le $\mathrm{VII}^{\mathrm{e}}$ siècle $\mathrm{EC}$, la laine était toujours la fibre de prédilection pour la production textile locale, alors que de conséquents corpus de tissus en coton apparaissaient notamment à Nahal 'Omer. Le coton était alors majoritairement filé en $-\mathrm{Z}$ et incluait de précieux ikats. Des pièces de vêtement et des linceuls de coton, filé en -S cette fois, furent également découverts à Qasr el-Yahud, sur les rives du Jourdain, et datent $d u V{ }{ }^{e}{ }^{e}-I^{e}$ siècle EC. Dans les collines du Qarantal surplombant Jericho, plusieurs fragments de tissus en coton furent aussi mis au jour dans la Grotte 38, dont d'intéressants spécimens teints en réserve datés du IXe à la fin du XIII ${ }^{\mathrm{e}}$ siècle EC.

Cet article offre au lecteur un large panorama des découvertes de textiles en coton sur le territoire de la Palestine ancienne. Il concentre son attention sur plusieurs sites-clés pour chaque période considérée, tout en listant les autres occurrences relevées dans la région. À travers la description de chaque ensemble textile seront discutés l'origine possible de ces tissus en coton et le co-développement du commerce textile et de la production locale, de l'Antiquité tardive aux périodes médiévales.

\section{INDEX}

Mots-clés: coton, ancienne Palestine, origine, teinture en réserve, Nahal 'Omer, Qasr el-Yahud, Grotte 38

Keywords: cotton, ancient Palestine, origin, resist-dyed textiles, Nahal 'Omer, Qasr el-Yahud, Cave 38

\section{AUTHOR}

\section{ORIT SHAMIR}

Head Department of Museums \& Exhibits, Curator of Organic Materials, Israel Antiquities Authority orit@israntique.org.il 